\title{
Encephalitis with Autoantibodies against the Glutamate Kainate Receptors GluK2
}

\author{
Jon Landa, BS $\odot,{ }^{1 \dagger}$ Mar Guasp, MD, ${ }^{1,2 \dagger}$ Federico Míguez-Cabello, BS, ${ }^{3}$ \\ Joana Guimarães, MD, PhD, ${ }^{4}$ Takayasu Mishima, MD, PhD, ${ }^{5}$ Fumiko Oda, MD, ${ }^{6}$ \\ Frauke Zipp, MD, PhD ${ }^{7}, 7$ Vladimir Krajinovic, MD, PhD, ${ }^{8}$ Peter Fuhr, MD, ${ }^{9}$ \\ Jerome Honnorat, MD, PhD, ${ }^{10}$ Maarten Titulaer, MD, PhD, ${ }^{11}$ Mateus Simabukuro, MD, ${ }^{12}$ \\ Jesus Planagumà, $\mathrm{PhD},{ }^{1}$ Eugenia Martínez-Hernández, $\mathrm{MD}, \mathrm{PhD},{ }^{1,2}$ \\ Thais Armangué, MD, PhD, ${ }^{1,13}$ Albert Saiz, MD, PhD, ${ }^{1,2}$ Xavier Gasull, PhD, ${ }^{1,3}$ \\ David Soto, MD, ${ }^{1,3}$ Francesc Graus, MD, PhD, ${ }^{1}$ Lidia Sabater, PhD $\mathbb{1}, 1^{1 \neq}$ \\ Josep Dalmau, MD, PhD, ${ }^{1,2,14,15,16 \ddagger}$ and GluK2 encephalitis study group
}

Objective: The objective of this study was to report the identification of antibodies against the glutamate kainate receptor subunit 2 (GluK2-abs) in patients with autoimmune encephalitis, and describe the clinical-immunological features and antibody effects.

Methods: Two sera from 8 patients with similar rat brain immunostaining were used to precipitate the antigen from neuronal cultures. A cell-based assay (CBA) with GluK2-expressing HEK293 cells was used to assess 596 patients with different neurological disorders, and 23 healthy controls. GluK2-ab effects were determined by confocal microscopy in cultured neurons and electrophysiology in GluK2-expressing HEK293 cells.

Results: Patients' antibodies precipitated GluK2. GluK2 antibody-specificity was confirmed by CBA, immunoprecipitation, GluK2-immunoabsorption, and GluK2 knockout brain immunohistochemistry. In 2 of 8 samples, antibodies reacted with additional GluK2 epitopes present in GluK1 or GluK3; in both, the reactivity was abrogated after GluK2 immuno-absorption. Six of 8 patients developed acute encephalitis and clinical or magnetic resonance imaging (MRI) features of predominant cerebellar involvement (4 presenting as cerebellitis, which in 2 patients caused obstructive hydrocephalus), and 2 patients had other syndromes (1 with cerebellar symptoms). One of the samples showed mild reactivity with non-kainate receptors (alpha-amino-3-hydroxy-5-methyl-4-isoxazolepropionic acid receptors [AMPAR] and N-methyl-D-aspartate receptors [NMDAR]) leading to identify 6 additional cases with GluK2-abs among patients with anti-AMPAR (5/71) or anti-NMDAR encephalitis (1/73). GluK2-abs internalized GluK2 in HEK293 cells and neurons;

View this article online at wileyonlinelibrary.com. DOI: 10.1002/ana.26098

Received Jan 14, 2021, and in revised form May 3, 2021. Accepted for publication May 3, 2021.

Address correspondence to Dr Lidia Sabater and Prof Josep Dalmau, IDIBAPS-Hospital Clínic, University of Barcelona, Casanova, 143 ; Floor 3 A, 08036 Barcelona, Spain. E-mail: lisabate@clinic.cat; jdalmau@clinic.cat

${ }^{\dagger}$ These authors have contributed equally.

*The authors have contributed equally as senior investigators.

From the ${ }^{1}$ Institut d'Investigacions Biomèdiques August Pi i Sunyer (IDIBAPS), Hospital Clínic, Universitat de Barcelona, Barcelona, Spain; ${ }^{2}$ Service of Neurology, Hospital Clinic, Barcelona, Spain; ${ }^{3}$ Neurophysiology Laboratory, Department of Biomedicine, School of Medicine, Neuroscience Institute, University of Barcelona, Barcelona, Spain; ${ }^{4}$ Neurology Department, Centro Hospitalar Universitário São João, Clinical Neurosciences and Mental Health Department, Faculty of Medicine, Porto, Portugal; ${ }^{5}$ Department of Neurology, Fukuoka University, Fukuoka, Japan; ${ }^{6}$ Department of Neurology, Graduate School of Medicine, Chiba University, Chiba, Japan; ${ }^{7}$ Neurology Department, Focus Program Translational Neurosciences (FTN) and Immunotherapy (FZI), Rhine Main Neuroscience Network (rmn2), University Medical Center of the Johannes Gutenberg University Mainz, Mainz, Germany; ${ }^{8}$ University Hospital for Infectious Diseases “Dr. Fran Mihaljevic", Zagreb, Croatia; ${ }^{~}$ Department of Neurology, University Hospital Basel, Basel, Switzerland; ${ }^{10}$ French Reference Center for Paraneoplastic Neurological Syndromes and Autoimmune Encephalitis, Hospices Civils de Lyon, Synatac Team, NeuroMyoGene Institute, INSERM U1217/CNRS UMR5310, University Claude Bernard, Villeurbanne, France; ${ }^{11}$ Department of Neurology, Erasmus MC University Medical Center, Rotterdam, The Netherlands; ${ }^{12}$ Department of Neurology, University of São Paulo Medical School, São Paulo, Brazil; ${ }^{13}$ Neuroimmunology Unit, Neurology Service, Sant Joan de Déu Children's Hospital, University of Barcelona, Barcelona, Spain; ${ }^{14}$ Centro de Investigación Biomédica en Red de Enfermedades Raras (CIBERER), Madrid, Spain; ${ }^{15}$ Department of Neurology, Perelman School of Medicine, University of Pennsylvania, Philadelphia, PA; and ${ }^{16}$ Catalan Institute for Research and Advanced Studies (ICREA), Barcelona, Spain 
these antibody-effects were reversible in neurons. A significant reduction of GluK2-mediated currents was observed in cells treated with patients' GluK2 serum following the time frame of antibody-mediated GluK2 internalization.

Interpretation: GluK2-abs associate with an encephalitis with prominent clinicoradiological cerebellar involvement. The antibody effects are predominantly mediated by internalization of GluK2.

ANN NEUROL 2021;90:101-117

$\mathrm{H}$ uman autoantibodies can impair central nervous system (CNS) excitatory synaptic transmission causing different syndromes with a range of manifestations that vary according to the target antigen. ${ }^{1}$ In the CNS, excitatory synaptic transmission is largely mediated by 3 types of ionotropic glutamate receptors: the N-methyl-Daspartate receptors (NMDARs), the alpha-amino3-hydroxy-5-methyl-4-isoxazolepropionic acid receptors (AMPARs), and the kainate receptors. Each of these receptors is composed of 4 subunits that form a central ion channel with a subunit composition that varies according to the type of receptor. ${ }^{2,3}$

In 2007, a linkage of clinical-immunological findings in patients with similar neurological symptoms of unknown etiology and antibodies that produced an identical pattern of brain immunostaining led to initially identify anti-NMDAR encephalitis ${ }^{4}$ and 2 years later, anti-AMPAR encephalitis. ${ }^{5}$ Whereas in anti-NMDAR encephalitis, the clinical features outlined a novel syndrome with a characteristic multistage neuropsychiatric presentation, ${ }^{6}$ in anti-AMPAR encephalitis, the clinical and magnetic resonance imaging (MRI) findings were frequently similar to limbic encephalitis. ${ }^{7,8}$ Common immunological characteristics of these 2 diseases are that the IgG antibodies are subclass IgG1, recognize extracellular epitopes, and cause internalization of the corresponding receptors. ${ }^{9,10}$

Here, we describe the clinical features, IgG subclass, subunit targets, and antibody effects in a group of patients with antibodies against the glutamate kainate receptor (GluK) subunit 2 (GluK2).

\section{Methods}

\section{Patients and Samples}

From January 2013 until September 2020, we identified 127 patients whose serum or cerebrospinal fluid (CSF) were investigated at Hospital Clinic IDIBAPS for suspected autoimmune CNS disorders and had antibodies that strongly reacted with the neuropil of rat brain and primary cultures of rat hippocampal or cerebellar granule neurons. Of these 127 patients, we selected serum and CSF samples from 8 patients that showed the same pattern of brain immunostaining, but different from those associated with anti-AMPAR, NMDAR, or any other known autoimmune encephalitis. As controls, we included serum of 23 healthy blood donors and serum or CSF of 596 patients with the following disorders: 73 with multiple system atrophy with predominant cerebellar phenotype, 73 with anti-NMDAR encephalitis, 71 with anti-AMPAR encephalitis, 48 with cerebellitis of unknown etiology, 40 with multiple sclerosis, 37 with paraneoplastic cerebellar degeneration, 30 with opsoclonus-myoclonus, 29 with non-hereditary degenerative ataxia, 23 with neuromyelitis optica spectrum disorder, 20 with encephalitis with neuronal surface antibodies other than NMDAR or AMPAR, 20 with progressive supranuclear palsy, 13 with Creutzfeldt-Jakob disease, and the remaining 119 cases of the initial group from which the 8 cases of the study were obtained.

The Ethic Committee of Hospital Clinic, Barcelona, approved the study (R091217-12). Patients or proxies gave consent for the storage and use of serum, CSF, and clinical information for research purposes.

\section{Immunohistochemistry with Brain Tissue and Immunofluorescence with Cultured Neurons}

Immunostaining of rat brain and wild-type or GluK2 knockout mice brain (kindly provided by Dr. Juan Lerma ${ }^{11}$ ) was performed with the patients' serum (diluted $1: 200)$ and CSF (1:2) using a standard immunoperoxidase technique. ${ }^{12}$ Immunofluorescence with primary cultures of rat hippocampal neurons was performed with serum $(1: 200)$ and CSF $(1: 5) .^{5}$

\section{Immunoprecipitation}

Cultures of rat cerebellar granule neurons and immunoprecipitation with patients' or control serum were performed as previously reported. ${ }^{13}$ Protein precipitates were first assessed by silver staining (A44390; Thermo-Fisher Scientific, Waltham, MA, USA), but all precipitated proteins were characterized by mass spectrometry without preselection of specific bands. In other experiments, HEK293 cells expressing the identified antigen (GluK2) were incubated with patients' or control serum, and subsequently lysed and precipitated as above. Precipitates from these HEK293 cells or neurons were then run in a gel, transferred to nitrocellulose, incubated with a polyclonal GluK2 antibody made in rabbit (diluted 1:500, HPA014623, Atlas Antibodies, Sweden), and the reactivity developed with chemiluminescence, as reported. ${ }^{13}$ 


\section{Cell-Based Assays}

To determine the repertoire of patients' antibodies against each of the human subunits of kainate receptors (GluK1, GluK2, GluK3, GluK4, and GluK5), HEK293 cells were transfected with plasmids containing each of the human subunit sequences tagged with MYC-DDK (all from Origene, Rockville, MD, USA) including: GRIK1 (RC222898), GRIK2 (RC222369), or GRIK3 (RC223571), which are able to form functional kainate-gated homomeric receptors. For GRIK4 (RC214488) and GRIK5 (RC224695), which only form functional receptors when co-expressed with GRIK1, GRIK2, or GRIK3, we used cotransfections with GRIK3/GRIK4 or GRIK3/GRIK5, as well as each subunit separately. The techniques of transfection and incubation of HEK293 cells with patients' samples (or cell-based assays [CBAs]) are identical to those previously reported. ${ }^{5,14}$ Briefly, live transfected HEK293 cells were incubated with serum (1:50) or CSF (1:5) for 1 hour at $37^{\circ} \mathrm{C}$. After fixation with $4 \%$ paraformaldehyde (PFA) and permeabilization with $0.3 \%$ Triton X-100, the cells were incubated with a mouse MYC-tag antibody (diluted 1:2500, 2276S; Cell Signaling Technology, Danvers, MA, USA) for 1 hour at room temperature (RT) followed by fluorescent secondary antibodies Alexa Fluor 488 goat anti-human (1:1000, 109-545-088, Jackson ImmunoResearch, Newmarket, UK) and Alexa Fluor 594 goat anti-mouse (1:1000, A-11005; Thermo-Fisher).

The presence of AMPAR or NMDAR antibodies was examined with CBA expressing GluA1/GluA2 subunits of AMPARs or GluN1/GluN2B subunits of NMDARs. ${ }^{5,15}$

To determine whether patients' antibodies were able to internalize GluK2 in HEK293 cells, live cells were treated for 30 minutes or 5 hours with patients' serum (diluted 1:100 in the media). After washing, live cells were incubated for 1 hour with excess of Alexa Fluor 488 goat anti-human IgG (diluted 1:20; Jackson ImmunoResearch) to block all cell-surface human $\operatorname{IgG}$, and then washed, permeabilized, and the internalized $\operatorname{IgG}$ was demonstrated with a differently labeled secondary anti-human antibody (Alexa Fluor 594 goat anti-human IgG, diluted 1:1000; 109-585-088; Jackson ImmunoResearch). All CBA studies were examined with a Zeiss AxioImager M2 fluorescent microscope with ApoTome.2 system (Carl Zeiss, Jena, Germany) and results were scanned with a Zeiss LSM710 confocal microscope (Carl Zeiss).

\section{IgG Subclass}

The IgG subclass of the antibodies was assessed using CBA with HEK293 cells expressing GluK2 and secondary anti-human antibodies specific for $\operatorname{IgG} 1, \operatorname{IgG} 2, \operatorname{IgG} 3$, and IgG4, as reported. ${ }^{16}$

\section{Immuno-absorption Studies}

Sera with reactivity restricted to GluK2 (ie, absent reactivity with other GluK subunits) or sera with GluK1/2/3 reactivity were serially incubated with 8 Petri dishes (60 $\mathrm{mm}$ diameter) containing live HEK293 cells expressing GluK2 or mock-transfected cells. Each of the 8 sequential incubations was for 1 hour at RT. The immune-absorbed sera were then examined with rat brain immunohistochemistry, live hippocampal neurons, and CBA, as reported. ${ }^{17}$

\section{Quantitative Analysis of GluK2 Clusters in Cultured Neurons Using Confocal Microscopy}

Rat hippocampal neurons were treated at 14DIV with CSF of 2 patients (case \#1 and case \#5) or control CSF (both 1:20 diluted) for 24 or 72 hours. Case 1 had antibodies reacting exclusively with GluK2; in case 5, some of the GluK2 epitopes were shared with GluK1; no other antibodies were present in these 2 cases. After removing the antibodies by changing the media, neurons were allowed to recover for 4 days. At the indicated time points ( 24 hours, 72 hours, and post 4-day recovery), neurons that had been exposed to patient's or control CSF were washed and incubated with human IgG isolated from serum with GluK2-abs (1:200, used here as primary antibody) for 1 hour at $37^{\circ} \mathrm{C}$. All GluK2 cell-surface receptors labeled with human $\operatorname{IgG}$ were then demonstrated with Alexa Fluor 488 goat anti-human IgG (1:1000, 109545-088, Jackson Immuno Research) for 1 hour at RT. Cells were then fixed with 4\% PFA for 5 minutes, permeabilized with $0.3 \%$ Triton X-100 for 5 minutes, and incubated with rabbit polyclonal PSD95 antibody (1:200, ab18258; Abcam, Cambridge, UK) for 1 hour, followed by the secondary antibody Alexa Fluor 594 goat anti-rabbit IgG (1:1000, A-11012; Thermo Fisher Scientific) for 1 hour at RT. Total and synaptic clusters of GluK2 were visualized by confocal imaging (LSM710; Carl Zeiss, Jena, Germany). Images were deconvolved using Huygens Professional version 17.04 (Scientific Volume Imaging, The Netherlands) and quantified using Imaris version 8.1 software (Oxford Instruments, Abingdon UK), as reported. ${ }^{18,19}$

\section{Electrophysiology in GluK2 Transfected HEK293 Cells}

HEK293T cells were transfected with $1 \mu \mathrm{g}$ total DNA from constructs codifying for GluK2(Q) and eGFP in a 9:1 (GluK2(Q):GFP) ratio, as reported. ${ }^{5,14}$ After 3-hour transfection, cells were split and yielded in glass coverslips treated with poly-L-lysine at low density. Twenty-four hours after transfection, coverslips were treated with 
patients' (case \#1 and case \#5) or control serum (diluted $1 / 100$ ) for 30 minutes or 5 hours, at $37^{\circ} \mathrm{C}$ and $5 \% \mathrm{CO}_{2}$.

Electrophysiological recordings were obtained within less than 1 hour after serum was removed and cells were placed in the recording chamber. Untagged non-edited GluK2(Q) subunit expression was determined by patching GFP positive cells. Transfected cells were visualized with an inverted epifluorescence microscope (Axio-Vert.A1; Carl Zeiss). Cells were continuously perfused at RT with extracellular physiological solution (in $\mathrm{mM}$ ): $145 \mathrm{NaCl}$, $2.5 \mathrm{KCl}, 1 \mathrm{CaCl}_{2}, 1 \mathrm{MgCl}_{2}, 10 \mathrm{HEPES}$, and 10 glucose, adjusted to $\mathrm{pH} 7.4$ with $\mathrm{NaOH}$. Whole-cell recordings were made from isolated cells using electrodes with opentip resistances of 2 to $4 \mathrm{M} \Omega(2.4 \pm 0.1 \mathrm{M} \Omega)$ made from borosilicate glass $(1.5 \mathrm{~mm}$ o.d., $0.86 \mathrm{~mm}$ i.d.; Harvard Apparatus, Sandbach, UK), pulled with a P-97 vertical puller (Narishige, London, UK), and giving a final series resistance of typically 6 to $10 \mathrm{M} \Omega(8.7 \pm 0.4 \mathrm{M} \Omega)$. Glutamate $10 \mathrm{mM}$ (Sigma-Aldrich) was applied to cells by piezoelectric translation (P-601.30; Physik Instrumente, Karlsruhe, Germany) of a theta-barrel application tool made from borosilicate glass $(1.5 \mathrm{~mm}$ o.d.; Sutter Instruments) at a holding potential of $-60 \mathrm{mV}$. Glutamate pulses were applied during 2 seconds every 20 seconds to allow GluK2 homomeric receptors to recover from desensitization. At the end of each recording, the adequacy of the solution exchange was tested by destroying the seal and measuring the liquid-junction current at the open pipette $(10-90 \%$ rise time normally $600-800 \mu \mathrm{s})$. Currents were acquired at $5 \mathrm{kHz}$ and low-pass filtered at $2 \mathrm{kHz}$ with an Axopatch 200B amplifier, Digidata 1440A interface and pClamp10 software (Molecular Devices, Sunnyvale, CA, USA). Intracellular pipette solution contained (in mM): $145 \mathrm{CsCl}, 2.5 \mathrm{NaCl}, 10 \mathrm{HEPES}, 1 \mathrm{Cs}-$ EGTA, and $4 \mathrm{MgATP}$, adjusted to $\mathrm{pH} 7.2$ with $\mathrm{CsOH}$. Recordings were analyzed using IGOR Pro (Wavemetrics, Tigard, OR, USA) with NeuroMatic (Jason Rothman, UCL, UK).

\section{Statistical Analyses}

In confocal microscopy studies, data are presented as box plots showing the median, and 25th and 75th percentile; whiskers indicate the minimum and maximum values. The effect of patients' serum compared with control serum on the number of neuronal clusters of GluK2 and PSD95 was normalized as the percentage against the median of the controls and analyzed with Kruskal-Wallis With Dunn's multiple comparison test. In electrophysiological studies, data are presented in the figures as bar plots of the mean with error bars denoting the SEM. Comparisons between groups were performed using the nonparametric Kruskal-Wallis with Dunn's multiple comparisons test. Differences were considered significant at $p<0.05$. Statistical analysis was performed using GraphPad Prism version 5.0d for Mac OS X (GraphPad Software, San Diego, CA, USA, www.graphpad.com).

\section{Results}

Sera of 2 patients (cases 1 and 2; Table 1) were used for antigen characterization. In both cases, the samples immunoreacted with an antigen expressed on the cellsurface of neurons and produced an identical pattern of brain immunostaining (Fig 1A-F).

Patient \#1: A 24-year-old man was brought to the emergency department for acute onset headache, nausea, and vomiting. Eight years earlier, he was treated for Hodgkin's lymphoma and since he had no evidence of disease. Preceding the current symptoms, the patient described several weeks of dizziness and photophobia. At examination, the memory, cognition, and cranial nerve function were intact, and no motor or sensory deficits were detected. The CSF showed 52 white blood cells $/ \mathrm{mm}^{3}$ and increased protein concentration $(1.18 \mathrm{~g} / \mathrm{L})$. Because of the suspicion of herpes simplex encephalitis, he was started on acyclovir until the polymerase chain reaction (PCR) results came back negative. On day 3 after admission, the headache worsened, and he developed clinical and MRI features of cerebellitis with edema and mass effect causing obstructive hydrocephalus (Fig 2, top row). Treatment with intravenous steroids and mannitol resulted in neurologic improvement. A body fluorodeoxyglucose (FDG)-positron emission tomography (PET) scan showed a hypermetabolic supraclavicular adenopathy with biopsy findings consistent with Hodgkin's lymphoma. He received chemotherapy and radiotherapy resulting in progressive improvement. At the last follow-up, 60 months after symptom onset, he was fully recovered.

\section{Identification of GluK2 as the Main Target Antigen}

Live neuron immunoprecipitation with the indicated patients' serum revealed 21 and 25 unique peptides, respectively, covering the $26 \%$ and the $33 \%$ of the rat GluK2 protein sequence (NP_062182.1). Peptides from other GluK subunits were also immunoprecipitated but with lower score: GluK1 (2 unique peptides), GluK3 (2 unique peptides), GluK4 (3 unique peptides), and GluK5 (5 unique peptides). The most abundant peptide was precipitated with both serum samples (peptide: MESPIDSADDLAK) and corresponds to an identical sequence shared by GluK1 (NCBI accession number: NP_001104584; 664-676 amino acids), GluK2 (NP_062182.1; 664-676 amino acids), and GluK3 


\begin{tabular}{|c|c|c|c|c|c|}
\hline $\begin{array}{l}\text { Case \# } \\
\text { Sex/age }\end{array}$ & GluK reactivity & Main symptoms & Brain MRI & CSF & Follow-up months, outcome \\
\hline $\begin{array}{l}1^{\mathrm{a}} \\
\mathrm{M} / 24\end{array}$ & GluK2 & $\begin{array}{l}\text { Headache, nausea, vomiting, } \\
\text { cerebellitis, obstructive } \\
\text { hydrocephalus, decrease level of } \\
\text { consciousness }\end{array}$ & $\begin{array}{l}\text { Bilateral FLAIR/T2 increased } \\
\text { signal in cerebellum; } \\
\text { hydrocephalus }\end{array}$ & $\begin{array}{l}\text { WBC } 52 \\
\text { Prot } 118\end{array}$ & 60 , full recovery \\
\hline $\begin{array}{l}2 \\
F / 15\end{array}$ & $\begin{array}{l}\text { GluK2 }^{\text {d }} \\
\text { epitopes in } \\
\text { GluK1, GluK3 }\end{array}$ & $\begin{array}{l}\text { Headache, vomiting, fever, } \\
\text { cerebellitis, hydrocephalus, } \\
\text { increased reflexes, upgoing toes, } \\
\text { and decreased level of } \\
\text { consciousness }\end{array}$ & $\begin{array}{l}\text { Bilateral DWI/FLAIR increased } \\
\text { signal in frontal, temporal, } \\
\text { cerebellar regions; } \\
\text { hydrocephalus }\end{array}$ & $\begin{array}{l}\text { WBC } 105 \\
\text { Prot } 22\end{array}$ & 36, partial recovery (mRS 2) \\
\hline $\begin{array}{l}3 \\
F / 14\end{array}$ & GluK2 & $\begin{array}{l}\text { Acute cerebellitis with } \\
\text { prominent cerebellar ataxia }\end{array}$ & N/A & N/A & N/A \\
\hline $\begin{array}{l}4^{\mathrm{b}} \\
F / 33\end{array}$ & GluK2 & $\begin{array}{l}\text { Headache, nausea, vomiting, } \\
\text { rapidly progressive cerebellitis, } \\
\text { prominent ataxia, myoclonus, } \\
\text { and later opsoclonus }\end{array}$ & $\begin{array}{l}\text { Mild cerebellar edema, } \\
\text { increased FDG-PET activity in } \\
\text { cerebellum }\end{array}$ & $\begin{array}{l}\text { WBC } 359 \\
\text { Prot } 520\end{array}$ & $\begin{array}{l}\text { 36, residual ataxia, mild } \\
\text { opsoclonus, able to walk and } \\
\text { perform activities of daily living }\end{array}$ \\
\hline $\begin{array}{l}5 \\
M / 75\end{array}$ & $\begin{array}{l}\text { GluK2 }^{\mathrm{d}} \\
\text { epitopes in } \\
\text { GluK1 }\end{array}$ & $\begin{array}{l}\text { Fever, behavioral change, } \\
\text { confusion, memory loss, } \\
\text { dizziness, decrease level of } \\
\text { consciousness, myoclonus, } \\
\text { bradykinesia, limb and gait } \\
\text { ataxia }\end{array}$ & $\begin{array}{l}\text { DWI/FLAIR increased signal in } \\
\text { cerebellum and medial temporal } \\
\text { lobes. No restriction on ADC }\end{array}$ & $\begin{array}{l}\text { WBC } 1 \\
\text { Prot } 45 \\
\text { OCB }+\end{array}$ & 6, partial recovery; died \\
\hline $\begin{array}{l}6 \\
\mathrm{M} / 73\end{array}$ & GluK2 & $\begin{array}{l}\text { HIV+, alcohol abuse; } 2 \text {-year } \\
\text { history of paresthesias in feet, } \\
\text { gait instability and mild } \\
\text { cognitive deficit. Sudden rapid } \\
\text { progression of spastic-ataxic } \\
\text { gait, confusion, saccadic } \\
\text { pursuit, increased reflexes, } \\
\text { upgoing toes. }\end{array}$ & Brain and cerebellar atrophy & $\begin{array}{l}\text { WBC } 20 \\
\text { Prot } 40 \\
5 \text { OCB; } \\
\text { normal tau, } \\
\text { phospho-tau }\end{array}$ & 27, died (cause unknown) \\
\hline $\begin{array}{l}7^{\mathrm{c}} \\
\mathrm{M} / 67\end{array}$ & GluK2 & $\begin{array}{l}\text { Nausea, vomiting, gait } \\
\text { instability. Ataxia, myoclonus, } \\
\text { choreoathetosis, weakness in } \\
\text { arms and legs. }\end{array}$ & Mild general atrophy & $\begin{array}{l}\text { WBC } 240 \\
\text { Prot } 72\end{array}$ & $\begin{array}{l}5 \text {, died in the acute phase of the } \\
\text { disease (sepsis) }\end{array}$ \\
\hline $\begin{array}{l}8 \\
M / 23\end{array}$ & GluK2 & $\begin{array}{l}\text { Insomnia, delusional thoughts, } \\
\text { agitation, seizures }\end{array}$ & $\begin{array}{l}\text { Multifocal FLAIR/T2 increased } \\
\text { signal in temporal lobes and } \\
\text { subcortical white matter }\end{array}$ & $\begin{array}{l}\text { WBC } 6 \\
\text { Prot } 86\end{array}$ & N/A \\
\hline
\end{tabular}

${ }^{a}$ Patient 1 had Hodgkin's lymphoma.

${ }^{\mathrm{b}}$ Patient 4 had ovarian teratoma and low titers of AMPAR, NMDAR, and glycine receptor antibodies.

${ }^{\mathrm{c}}$ Patient 7 had history of retroperitoneal teratoma removed without current evidence of tumor.

${ }^{\mathrm{d}} \mathrm{GluK} 1$ and GluK3 reactivity abrogated after absorption with GluK2. In all cases, GluK2-abs were demonstrated in serum and CSF.

$\mathrm{ADC}=$ apparent diffusion coefficient; AMPAR = alpha-amino-3-hydroxy-5-methyl-4-isoxazolepropionic acid receptor; CSF = cerebrospinal fluid; $\mathrm{DWI}=$ diffusion-weighted imaging; $\mathrm{F}=$ female; FDG = fluorodeoxyglucose; FLAIR = fluid-attenuated inversion recovery; HIV = human immunodeficiency virus; $\mathrm{M}=$ male; $\mathrm{MRI}=$ magnetic resonance imaging; $\mathrm{N}=$ normal; $\mathrm{N} / \mathrm{A}=$ not applicable; NMDAR $=\mathrm{N}$-methyl-D-aspartate receptor; $\mathrm{OCB}=$ oligoclonal bands; $\mathrm{PET}=$ positron emission tomography; Prot = protein concentration $(\mathrm{mg} / \mathrm{dl}) ; \mathrm{WBC}=$ white blood cell count $(\mathrm{cells} / \mu \mathrm{l})$.

(NP_001106187.1; 666-678 amino acids) located in the extracellular S2 segment of the ligand binding domain of the protein. Silver-stained gel run in parallel with an immunoblot showing the GluK2 band is shown in Figure 3A.

\section{GluK2 CBA Test and IgG1 Antibody Subclass}

All 8 patients initially selected for their similar pattern of brain immunostaining showed robust reactivity with HEK293 cells transfected with GluK2, providing a CBA (Fig 3B-G). Considering that the amino acid sequence of 
GluK2 is $-80 \%$ identical to GluK1 and GluK3, and - $40 \%$ identical to GluK4 and GluK5, ${ }^{20}$ we examined the samples of all 8 patients for additional reactivity with GluK1 and GluK3, and available samples from 7 patients for GluK4 and GluK5 reactivity. In 2 cases, some of the GluK2 epitopes were shared with GluK1 or GluK3 (see Table 1). None of the assessed cases had antibodies reacting with GluK4 or GluK5 (data not shown) suggesting that the precipitated peptides of these subunits were brought down by receptors composed of GluK2/ GluK4 or GluK2/GluK5. In all 8 cases, the GluK2-abs titers, measured by serial sample dilution, were $>1: 50$ CSF, and > 1:200 serum, and all were IgG1 (not shown).

The specificity of GluK2 antibody reactivity was confirmed by CBA (Fig 3B-G), immunoprecipitation (Fig 3H), and immunohistochemistry with GluK2 knockout brain tissue (Fig 3I-R). Among the 8 index cases, samples of 7 cases did not react with GluK2 knockout brain, including the 2 cases in which some GluK2 epitopes were shared with GluK1 or GluK3, suggesting the shared epitopes did not contribute to tissue staining. In addition, immune-absorption with GluK2 abrogated the reactivity of the samples of the 7 patients (example shown in Fig 4); the only case with mild residual reactivity was case 4 who had low titer additional antibodies with NMDAR, AMPAR, and GlyR (not shown).

\section{Detection of GluK2-Abs in Other Anti-Glutamate Receptor Encephalitis}

The finding of additional antibodies against other glutamate receptors in case 4 , and the fact that GluK2 has - 40\% amino acid identity with GluA1/GluA2 subunits of the AMPAR (which are the antigens in anti-AMPAR encephalitis), and $-25 \%$ amino acid identity with subunits of the NMDARs, led us to determine GluK2-abs in 71 randomly selected patients with anti-AMPAR encephalitis and 73 with anti-NMDAR encephalitis. Among these 144 cases, GluK2-abs were found in 5 of 71 with antiAMPAR encephalitis and 1 of 73 with anti-NMDAR encephalitis. All 6 GluK2-abs positive patients in this group had high NMDAR and AMPAR antibody titers (all CBA, CSF titer $>1: 200)$ and relative lower titers of GluK2-abs (CSF CBA < 1:50). A summary of the clinical information, antibody associations, and comorbidities is provided in the last section of Results. GluK2-abs were not found in the serum or CSF of the remaining 458 patients with autoimmune or neurodegenerative disorders or in the serum of 23 healthy blood donors.

\section{Patients' Antibodies Cause a Decrease of GluK2 Clusters in Live Rat Hippocampal Neurons}

Neurons treated with patients' CSF (cases 1 and 5) compared with those treated with control CSF, showed a significant reduction of cell-surface clusters of GluK2 (Fig 5). Longer treatment with patients' CSF (eg, 72 vs. 24 hours) caused more robust effects (see Fig 5A, B, E). In contrast, the clusters of PSD95 were unaffected (see Fig 5A, C, F). After changing the media to remove the antibodies, allowing the neurons to recover for 4 days, the levels of GluK2 clusters returned to values similar to those of controls (see Fig 5A, B, D, E, G).

\section{Patients' Antibodies Impair GluK2-Mediated Currents}

The effects of patients' antibodies on GluK2-mediated currents were examined with samples from patients 1 and 5 using HEK293 cells expressing GluK2 (Fig 6A, B). Compared with nontreated cells or cells treated with serum of a healthy subject, the cells treated with patients' sera showed a significant decrease of GluK2-mediated currents (see Fig 6A, B). The impairment of GluK2-mediated currents occurred only in cells that had been exposed for several hours ( -5 hours) to patients' serum but not in cells that had very short incubations (eg, 30 minutes). Considering that after 30 minutes incubation there was extensive antibody binding to GluK2 (Fig 6C), the lack of electrophysiological effects by the bound antibodies suggests that they do not block or have a direct antagonistic effect on GluK2 function. Thus, the reduction of GluR2-mediated currents observed at 5 hours is likely due to receptor internalization and clustering. ${ }^{21}$ This paradigm is similar to that of other glutamate receptor antibodies (NMDAR or AMPAR), which impair receptor function mainly by internalization, ${ }^{10,22}$ and is different from that of glycine receptor antibodies, which cause functional blocking of the receptor after very short $(<30)$ incubations. $^{21}$

\section{Clinical and Immunological Spectrum of GluK2 Autoantibodies}

A summary of the 8 patients that originated this study is shown in Table 1 (cases \#1-8). The median age at disease onset was 28 years (range $=14-75$ years), 5 were men. In all but 1 patient (who had previous HIV-related neurological symptoms), the new onset of neurological symptoms progressed rapidly (<6 weeks) until reaching the peak of the disease. Four patients, median age 19 years (range $=14-33$ years) presented with prominent clinical manifestations compatible with cerebellitis, including opsoclonus in one of them. Two of them developed obstructive hydrocephalus, one treated with ventricular drainage and the other controlled with mannitol. Three patients $(23,67$, and 75 years old) developed a more diffuse encephalitis with prodromal flu-like symptoms followed by limb or gait ataxia (2 cases) and confusion, 

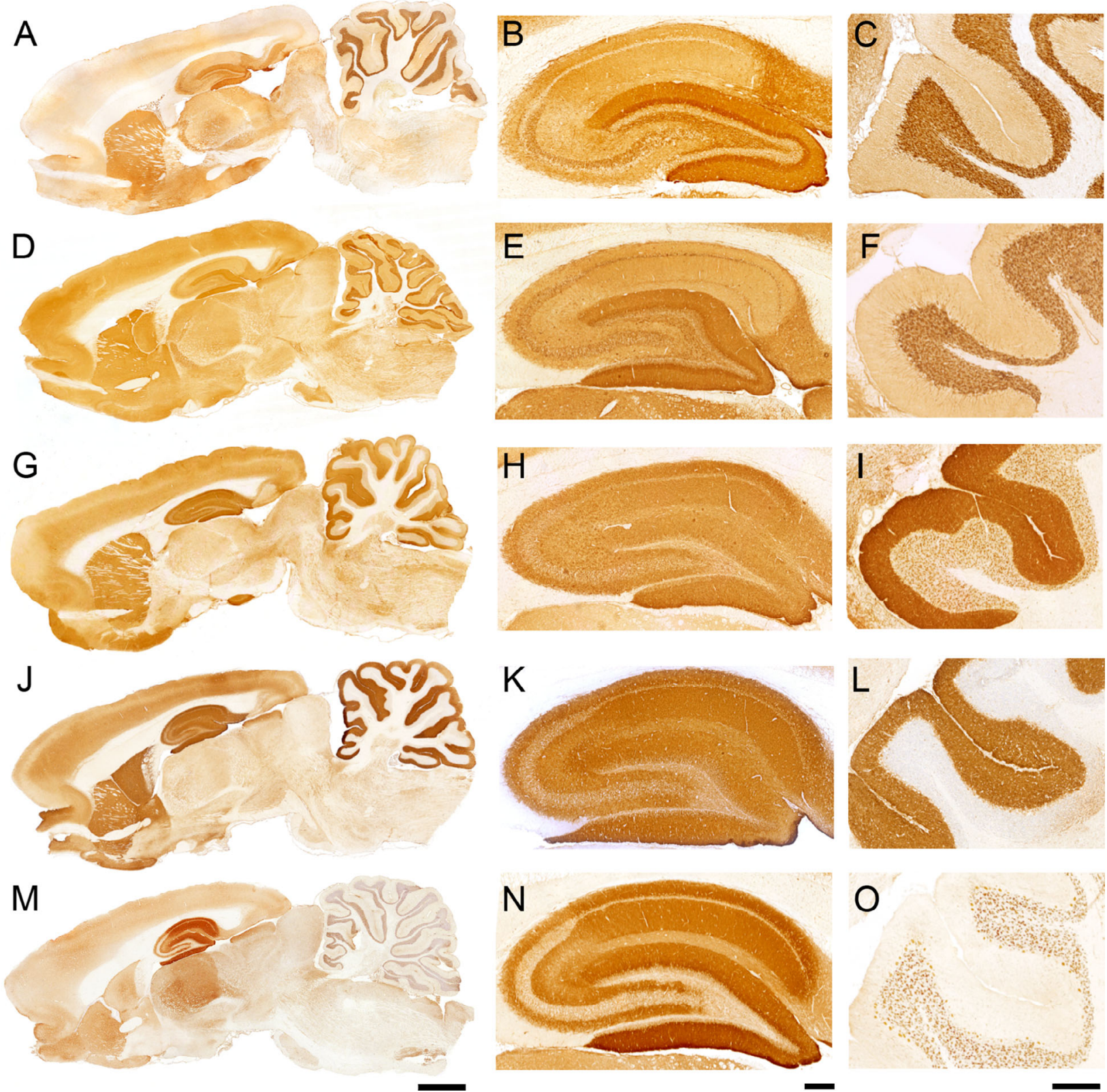

FIGURE 1: Brain immunostaining with cerebrospinal fluid (CSF) from patients with GluK2-abs compared with that of patients with alpha-amino-3-hydroxy-5-methyl-4-isoxazolepropionic acid receptor (AMPAR) and N-methyl-D-aspartate receptor (NMDAR), or combined antibodies. Sagittal sections of rat brain immunostained with CSF from 2 patients (case 1, A-C and case 2, D-F) showing a novel pattern of neuropil reactivity (subsequently characterized as due to GluK2-abs). The third row of panels (G-I) corresponds to a patient with antibodies against AMPAR and GluK2. Both antibodies intensively react with hippocampus (H) producing a mixed immunostaining; however, in cerebellum (I) the staining of the molecular layer results from AMPAR antibodies, and the staining of granular cells from GluK2 antibodies (I). For comparison with other glutamate receptor antibodies, the fourth and fifth rows correspond to CSF from a patient with anti-AMPAR (J-L) and a patient with NMDAR encephalitis (M-O) and show the distinct pattern of brain reactivity of each antibody (none of the 2 cases had GluK2 antibodies). Scale bars, $\mathrm{G}=2 \mathrm{~mm} ; \mathrm{H}=250 \mu \mathrm{m} ; \mathrm{I}=250 \mu \mathrm{m}$.

disorientation, delusional thoughts, psychomotor agitation, myoclonus, or seizures. The other patient was a 73-year-old man with history of alcohol abuse, HIV positive for 13 years (well controlled with 4 antiretrovirals), who developed rapid ( -3 months) neurological deterioration without evidence of HIV exacerbation (CD4 count $240 / \mathrm{ml}$; viral load suppressed) and CSF inflammatory findings $(20 \mathrm{WBC} / \mathrm{ml} ; 5$ oligoclonal bands, normal tau and phospho-tau) that suggested an autoimmune encephalitis (see Table 1, case 6). 

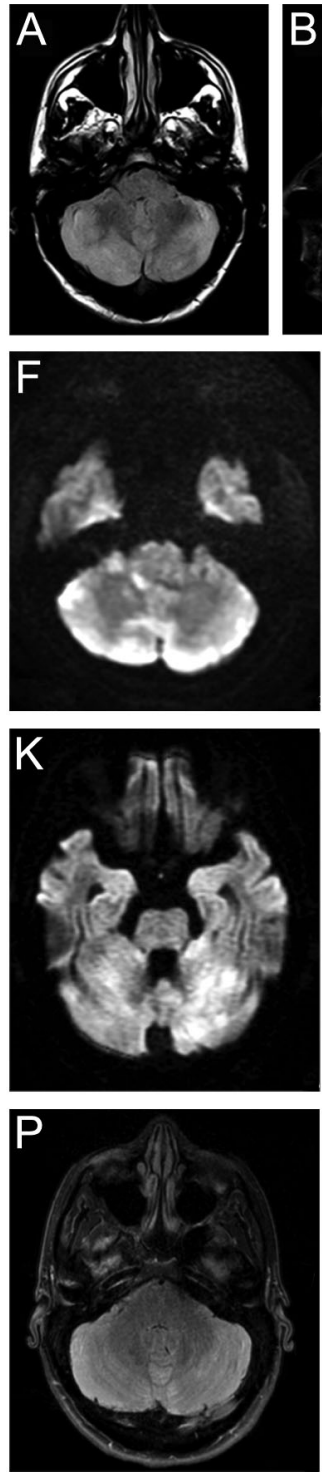
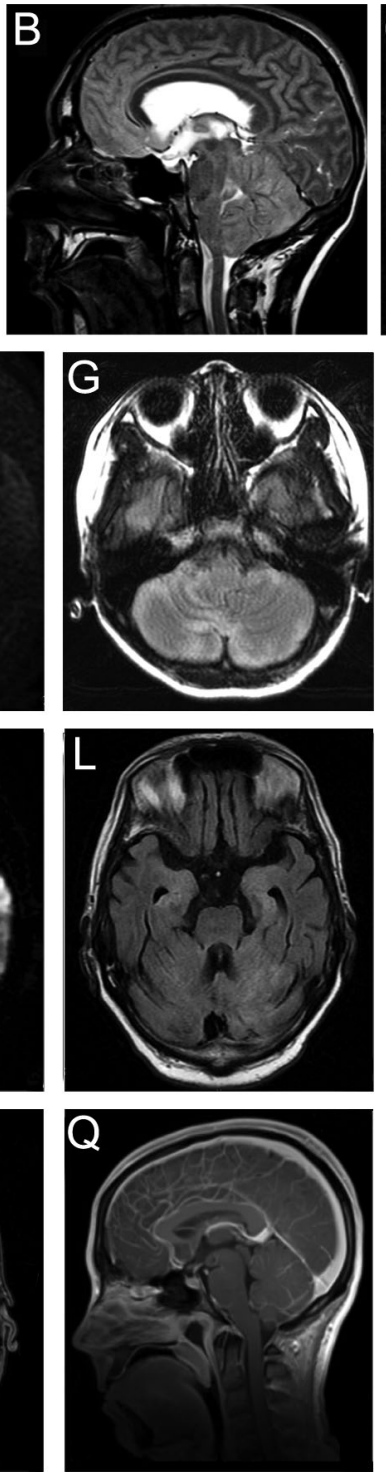
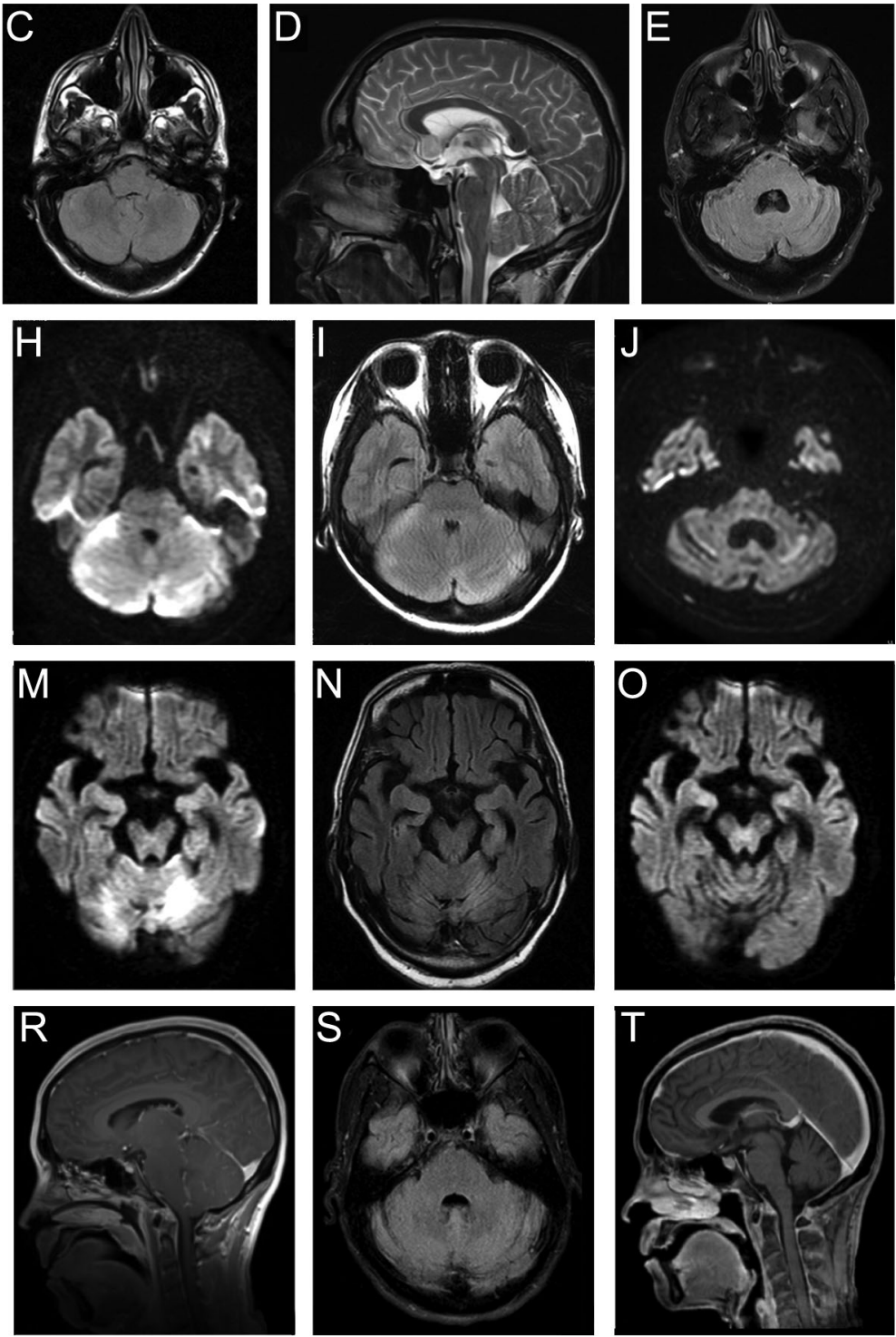
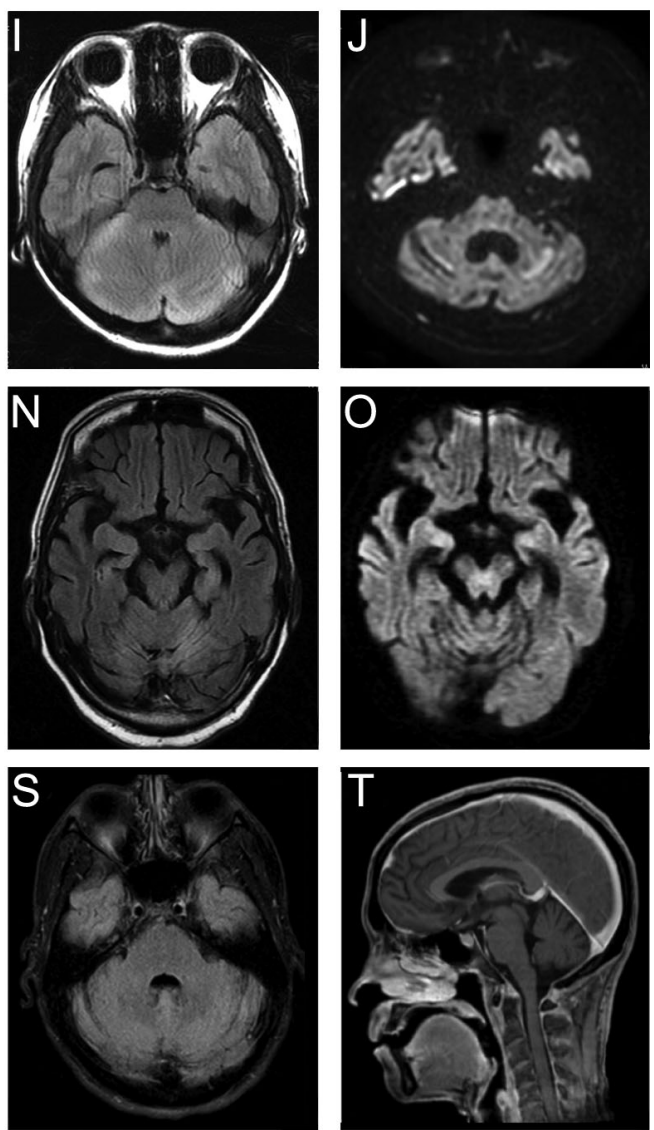

FIGURE 2: Brain magnetic resonance imaging (MRI) scans in 4 patients with GluK2 antibody associated cerebellitis. (A-E) Patient 1: Shows fluid-attenuated inversion recovery (FLAIR)-T2 MRI sequences of selected axial and sagittal sections obtained at symptom onset (A, B), 2 weeks later (C, D), and at the last follow-up (E). Note the presence of bilateral cerebellar abnormalities with edema and compression of the fourth ventricle at onset, with partial improvement 2 weeks later, and normal features 5 years later. (F-J) Patient 2: Shows diffusion-weighted imaging (DWI) (F, H, J) and FLAIR-T2 (G, I) MRI sequences obtained at symptom onset $(\mathrm{F}-\mathrm{I})$ and 2 years later $(\mathrm{J})$. There are bilateral, predominantly cortical, cerebellar abnormalities, best seen with DWI, with mass effect on the fourth ventricle, and the vermis was similarly involved. No restriction was observed on apparent diffusion coefficient (ADC) maps (not shown). At the last follow-up, most of the DWI abnormalities had resolved, but there was moderate residual atrophy $(\mathrm{J})$. (K-O) Patient 5: Shows the DWI (K, M, O) and FLAIR-T2 (L, N) MRI sequences obtained at symptom onset $(K-N)$ and 5 weeks later $(O)$. Note the extensive abnormalities bilaterally involving the cerebellum and vermis, best seen in DWI sequences; there is milder involvement of the temporal lobes (left > right). On ADC maps, no restriction was observed. Five weeks after symptom onset, most of the DWI abnormalities had improved. (P-T) Patient 4: Shows FLAIR (P, S) and $T 1$ with contrast $(Q, R, T)$ MRI sequences obtained at presentation $(P-R)$, and 1.5 years after disease onset $(S, T)$. At disease onset, there is moderate cerebellar edema with reduction of size of the fourth ventricle.

MRI studies were available from 7 patients: 4 showed multifocal T2-fluid-attenuated inversion recovery (FLAIR) abnormalities in the cerebellum with or without cerebral involvement (see Fig 2, 1st and 2nd rows), one (case \#5) had a clinical-radiological dissociation with mild cerebellar symptoms but extensive MRI cerebellar abnormalities (see
Fig 2, 3rd row). Another patient showed moderate cerebellar edema (see Fig 2, 4th row) with increased FDGPET activity, and the remaining 2 patients had brain and cerebellar atrophy (not shown). Six of these 7 patients had CSF pleocytosis. Two patients had active tumors (1 relapsing Hodgkin's lymphoma, and 1 ovarian teratoma) that 

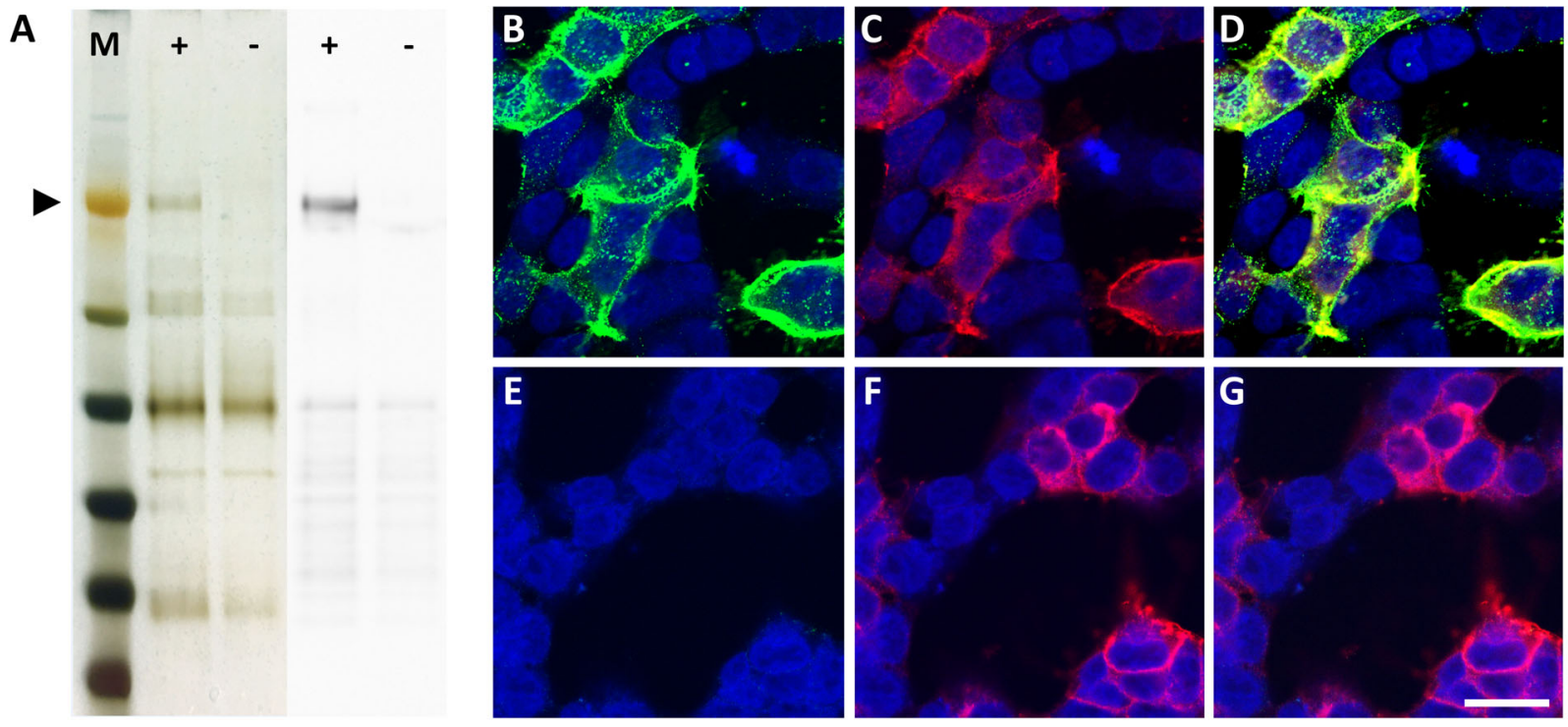

H
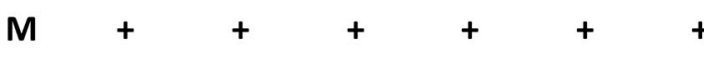

$\mathbf{T}$

UT

$96 \mathrm{KDa}$
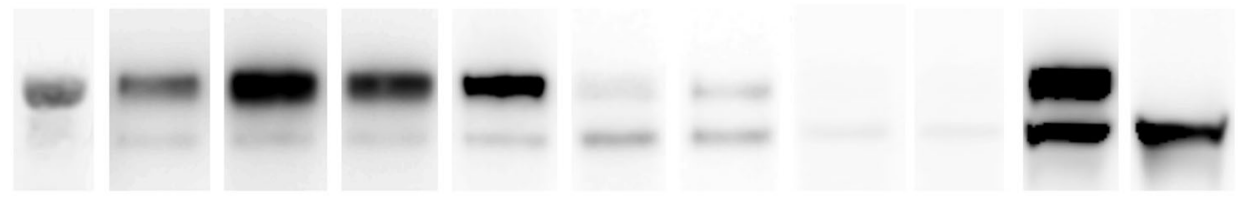

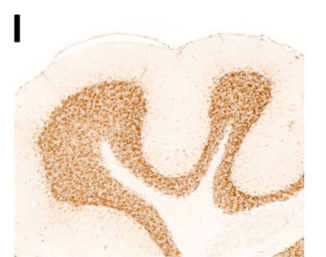

N

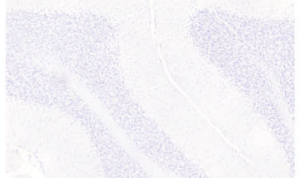

J

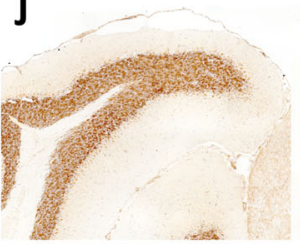

0

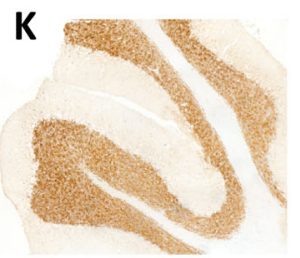

P

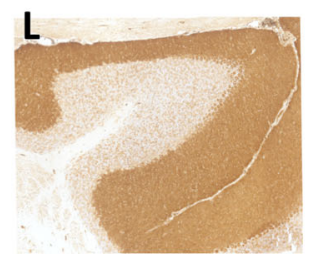

Q

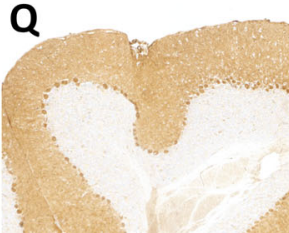

M

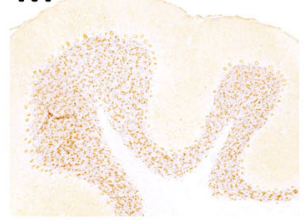

R

FIGURE 3: Cell-based assay and immunoprecipitation of GluK2. (A) Lanes 2 and 3 show the silver staining of proteins precipitated with serum of patient $1(+)$ and a control serum (-). Molecular markers are shown in lane M (arrow head $\sim 96 \mathrm{kDa}$ ). Lanes 4 and 5 show the corresponding immunoblot with a commercial GluK2 antibody demonstrating that the top band precipitated with patient's sample is GluK2. (B-D) Cell-based assay with HEK293 cells expressing GluK2 immunolabelled with patient's serum antibodies (green), or a commercial antibody against Myc-tag to confirm the expression of GluK2 (red). Panel D shows the merged reactivities. Panels ( $E-$ G) correspond to a similar CBA using serum from a healthy subject that demonstrates lack of reactivity with GluK2 (E). The nuclei of the cells (blue) is shown with 4',6-diamidino-2-phenylindole (DAPI). Scale bar $=20 \mu \mathrm{m}$. (H) Immunoblot showing the immunoprecipitation of GluK2 from live HEK293 cells expressing GluK2 and patients' or control sera. Lanes (+) correspond to GluK2 precipitated with serum from 6 patients; lanes $(-)$ show the lack of GluK2 precipitation using serum from 2 healthy participants; lane $M$ is the molecular weight marker; lane T corresponds to a lysate of HEK293 cells expressing GluK2, and lane UT correspond to a lysate of HEK293 cells not transfected with GluK2. In all lanes GluK2 was revealed with a polyclonal GluK2 antibody made in rabbit. (I-R) Immunostaining of cerebellum of wild-type mouse (I-M) and GluK2 knockout mouse (N-R) using cerebrospinal fluid (CSF) of 5 different patients: $I$ and $N$ Patient $1 ; \mathrm{J}$ and $\mathrm{O}$ patient 3; $\mathrm{K}$ and $\mathrm{P}$ patient 5; $\mathrm{L}$ and $\mathrm{Q}$ patient 10 (with GluK2 and alpha-amino3-hydroxy-5-methyl-4-isoxazolepropionic acid receptors [AMPAR] antibodies), and M and R patient 14 (with GluK2 and N-methyl-Daspartate receptor [NMDAR] antibodies). Scale bar $=250 \mu \mathrm{m}$. 

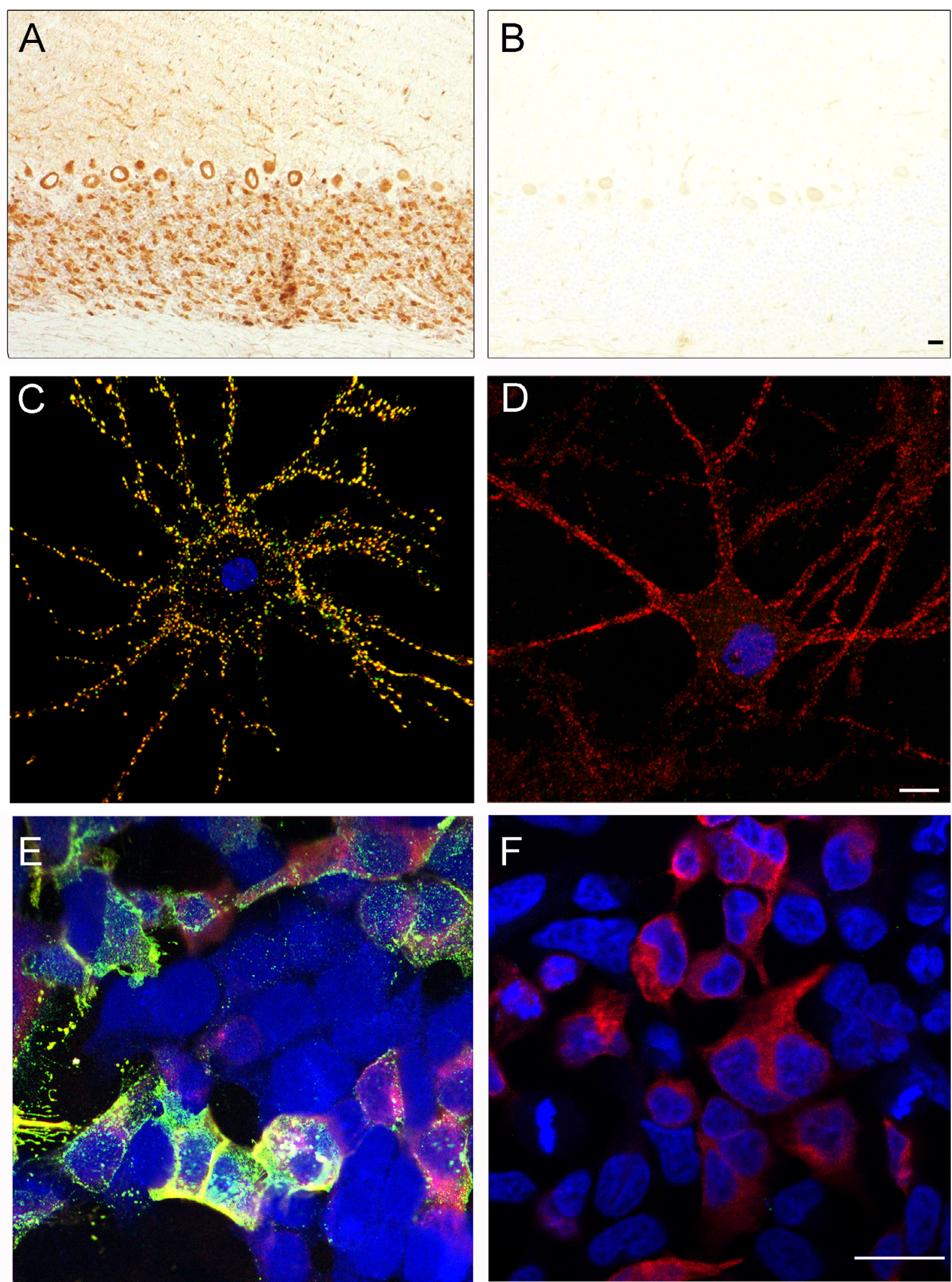

FIGURE 4: Pre-absorption of patient's serum with GluK2 abrogates brain immunoreactivity. Patient's serum reactivity with cerebellum (A, B), live hippocampal neurons (C, D), and a live cell-based assay expressing GluK2 (E, F). Panels on the left correspond to patient's serum preabsorbed with HEK293 cells not expressing GluK2, and panels on the right correspond to the same serum preabsorbed with HEK293 cells expressing GluK2. In C and D, cells have been co-incubated with patient's serum (green fluorescence) and a commercial GluK2 antibody (red fluorescence); the yellow staining corresponds to merged reactivities. In $E$ and $F$, the red immunofluorescence is a commercial antibody against Myc-tag to confirm that the cell-based assay (CBA) cells express GluK2. Note that pre-absorption with GluK2 abrogates the reactivity of patient's serum with cerebellum, live neurons, and live CBA (B, D, F). Scale bars $B, D, F=20 \mu \mathrm{m}$. 
A
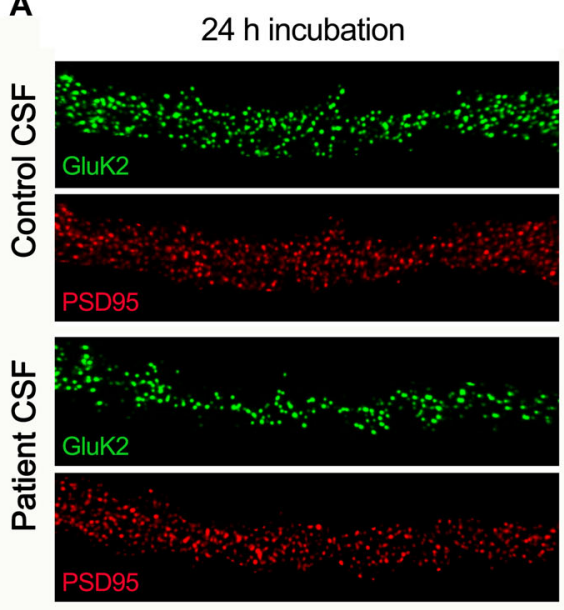

B

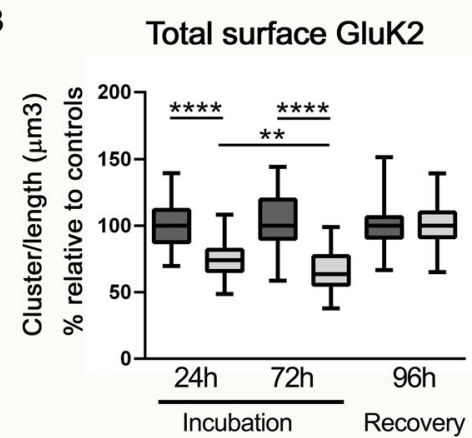

$\mathbf{E}$

Total surface GluK2

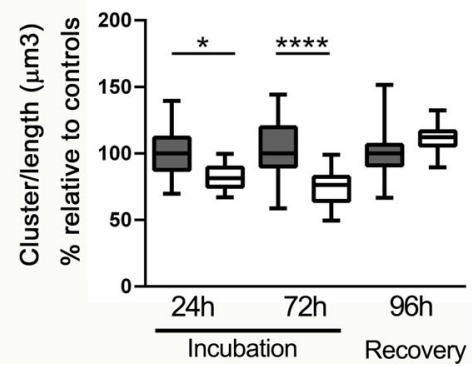

$72 \mathrm{~h}$ incubation
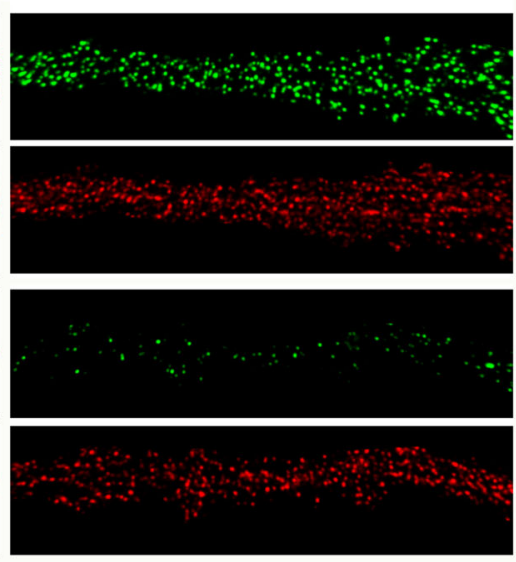

$96 \mathrm{~h}$ recovery
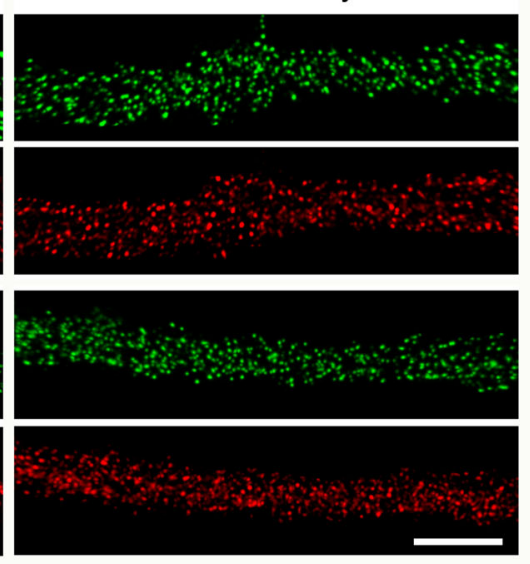

C

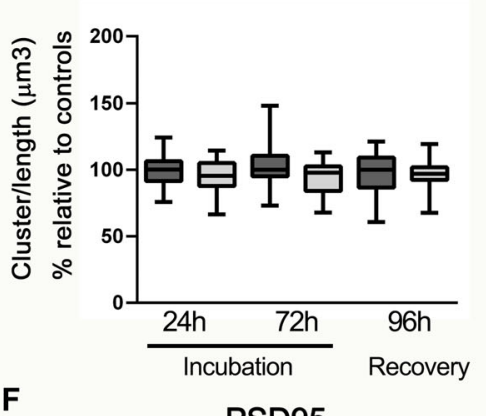

D

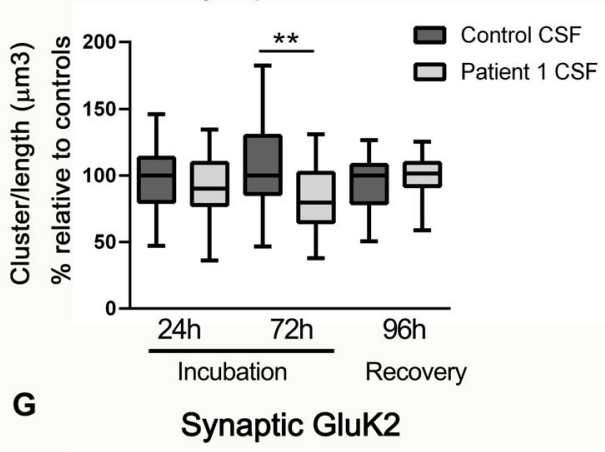

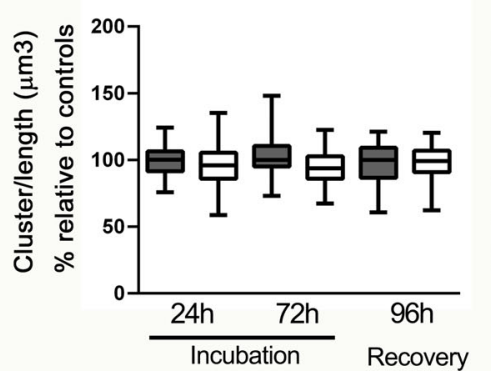

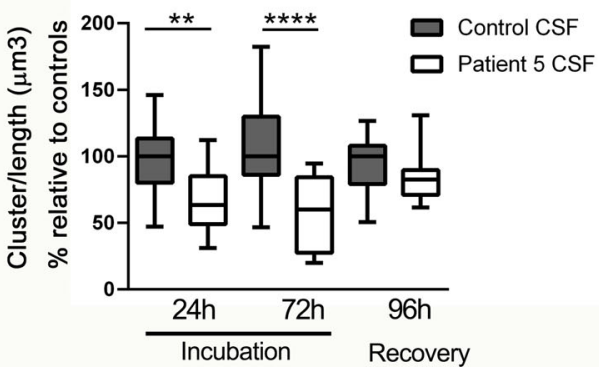

FIGURE 5: Patient's antibodies cause a reduction of cell-surface and synaptic GluK2 in cultured neurons. (A) Shows that the cerebrospinal fluid (CSF) of a representative patient (case 1), but not control CSF, causes a progressive decrease of GluK2 clusters in representative dendrites of cultures of rat hippocampal neurons. Note that the levels of clusters return to normal after removing the antibodies from the media and allowing the neurons to recover for 96 hours. Scale bar $=5 \mu \mathrm{m}$. (B-D) Show the quantification of these effects using CSF from patient 1 and (E-G) from patient 5 on total neuronal surface GluK2 (B, E) and synaptic GluK2 (D, G) defined by the co-localization of surface GluK2 with PSD95. The effects on GluK2 are reversible after the 96 hour recovery. Compared with control CSF, the CSF of the patients did not change the levels of PSD95 (C, F). $n=20$ dendrites per condition, 3 independent experiments. Data presented as percentage against the median of the controls. Box plots show the median, and 25th and 75th percentiles; whiskers indicate the minimum and maximum values. Significance of treatment effect was assessed by Kruskal-Wallis with Dunn's multiple comparison $* p<0.05 ; * * p<0.01 ; * * * p<0.0001$.

were successfully treated, and one had a retroperitoneal teratoma removed 1 year before neurological symptom onset, without tumor relapse. Seven patients were treated with steroids, and 2 of them received immunomodulation (patient 6: IVIg; and patient 4: IVIg, plasma exchange, rituximab, and cyclophosphamide). Three patients had partial or full recovery, 2 died in the acute phase of the disease (1 from multiple systemic complications and
1 from sepsis), 1 with HIV died 27 months after disease onset of unknown cause, and 1 was lost to follow-up. From the remaining patient (case 3 ), information beyond symptom presentation was not available; however, she was a 14-year-old girl who developed cerebellitis with acute cerebellar ataxia.

Separate from the 8 index cases with GluK2-only or predominant antibodies, there were 5 patients with anti- 
A

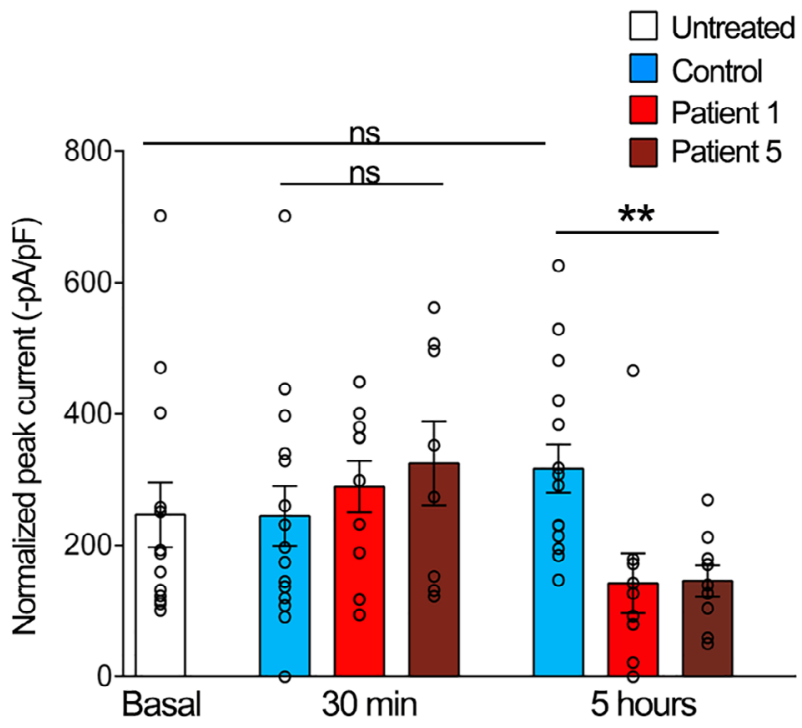

C

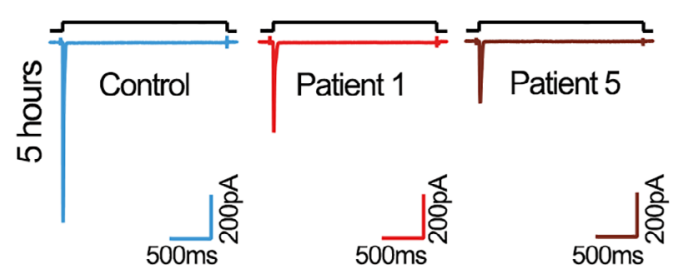

Glutamate $10 \mathrm{mM}$

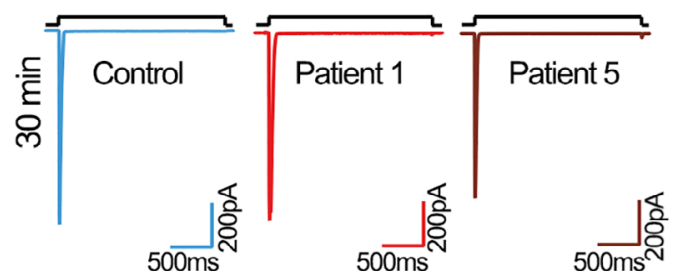

GluK2 (Patient 1)
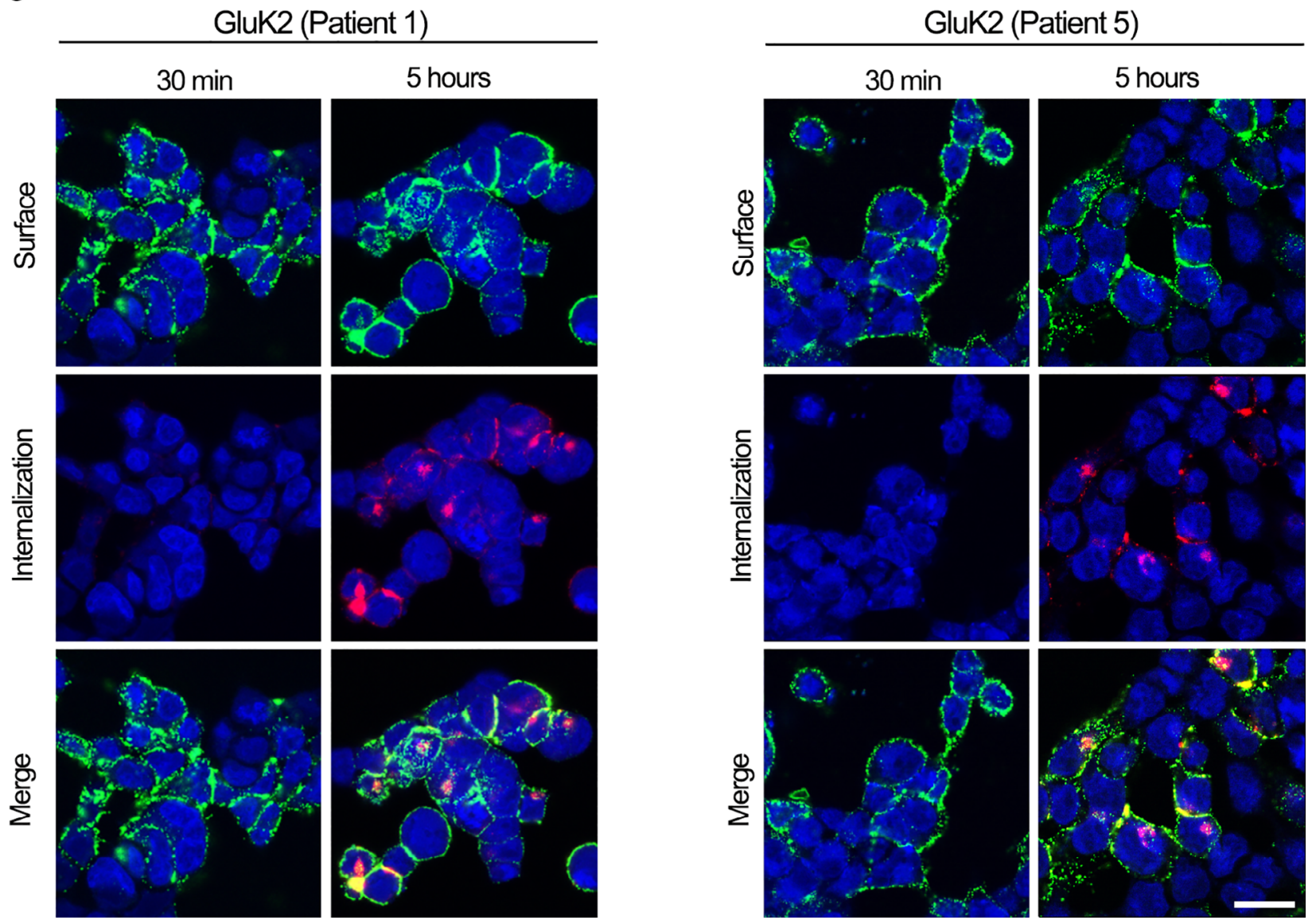

FIGURE 6: Patient's serum decreased GluK2-mediated currents. (A, B) Correspond to HEK293 cells expressing GluK2 (Q) treated for 30 minutes or 5 hours with control serum or 2 patients' serum. Current responses were activated by ultra-rapid application of $10 \mathrm{mM}$ glutamate in the cells at $-60 \mathrm{mV}$. In A the upper traces show the current responses of cells treated for 30 minutes with the indicated samples, and the lower traces show the current responses treated for 5 hours with the same samples (each of the traces represents the average of 4-7 consecutive glutamate applications). The average and SEM of glutamate-evoked normalized peak currents for cells untreated (basal), incubated with control serum, or 2 patients' serum are shown in B. Circles denote single values for each experiment. The GluK2-mediated currents of cells treated for 30 minutes (244.7 $\pm 45.39 \mathrm{pA} / \mathrm{pF})$ or 5 hours with control serum $(317 \pm 36.84 \mathrm{pA} / \mathrm{pF})$ were similar to those of untreated cells $(246.6 \pm 49.40 \mathrm{pA} / \mathrm{pF} ;)$ and also similar (Figure legend continues on next page.) 
AMPAR and 1 with anti-NMDAR encephalitis that had concurrent GluK2-abs (Table 2). Four of the 5 cases with AMPAR antibodies had tumors (3 had thymomas and 1 had small cell lung cancer [SCLC]). The 3 cases with thymoma had several additional antibodies (2 had CRMP5 and 1 had AChR, CASPR2, and GABAbR) and all showed a pattern of brain immunostaining composed of mixed reactivities (see Fig 1, 3rd row). In one of the cases with concurrent AMPAR antibodies and in the case with NMDAR antibodies, the brain immunostaining did not show the GluK2 reactivity. None of the 6 patients with concurrent antibodies developed clinical-radiological features of cerebellar dysfunction, and all showed a syndrome compatible with the concurrent antibodies.

\section{Discussion}

We found that glutamate kainate receptors containing GluK2 (previously known as GluR6) are the target of antibodies in some patients with encephalitis or cerebellitis of unclear etiology, and that these antibodies are likely pathogenic. This is supported by several findings: (1) the antibodies react with extracellular GluK2 epitopes in cultures of live rat hippocampal neurons and GluK2-expressing HEK293 cells; (2) they are IgG1 and internalize GluK2 receptors leading to a significant, but reversible, decrease of synaptic and extrasynaptic clusters of GluK2; (3) they also cause a significant reduction of GluK2-mediated currents in HEK293 cells expressing these receptors, and (4) some patients responded to empiric steroids or first line immunotherapy.

The kainate receptors are tetrameric ionotropic glutamate receptors that may include GluK1, GluK2, GluK3, GluK4, or GluK5, previously known as GluR5, GluR6, GluR7, KA1, and KA2. ${ }^{3}$ GluK1, GluK2, and GluK3 form functional homo- and heterotetrameric receptors, whereas GluK4 and GluK5 form functional receptors only when co-expressed with GluK1 to GluK3. ${ }^{3}$ As in the case of the GluA2 subunit of the AMPARs, GluK1 and GluK2 present $\mathrm{Q} / \mathrm{R}$ editing at the second transmembrane domain (TM2). This Q-to-R substitution abolishes $\mathrm{Ca}^{2+}$ permeability while increases $\mathrm{Cl}^{-}$permeation of the channel. ${ }^{23,24}$ In addition, Q residues account for larger conductance and inward rectification. ${ }^{25}$ In the current study, $\mathrm{Q} / \mathrm{R}$ editing did not modify the antibody reactivity with GluK2 (data not shown).

The kainate receptors are unconventional members of the glutamate receptor family in that, different from NMDAR or AMPAR, they are not predominantly found in excitatory postsynaptic complexes. In addition to function as ionotropic receptors, kainate receptors act as modulators for synaptic transmission and neuronal excitability interacting with metabotropic signaling pathways. ${ }^{3}$ They play a crucial role as presynaptic regulators of neurotransmitter release at both excitatory and inhibitory synapses by mechanisms not completely understood, ${ }^{26,27}$ are able to facilitate short-term and long-term plasticity ${ }^{28,29}$ and can act as modulators of GABAergic transmission. ${ }^{30}$

Our initial goal to characterize the autoantigen of a group of 8 patients with antibodies that showed a similar pattern of brain immunostaining was expanded after finding that the antigen was GluK2, which has a protein sequence highly similar to other glutamate receptor subunits ( $-80 \%$ identity with GluK1, GluK3; $-40 \%$ with GluK4, GluK5 and GluA1, GluA2 of AMPAR; and $-25 \%$ with NMDAR subunits). ${ }^{20}$ Thus, it was not surprising that the antibodies of some patients cross-reacted with epitopes shared with GluK1/GluK3, as demonstrated by immune-absorption studies. However, investigations with patients that had otherwise classical anti-AMPAR or NMDAR receptor encephalitis resulted in the identification of a group of 6 patients, mostly with AMPAR antibodies, who had concurrent GluK2-abs. Compared with the 8 index cases with GluK-only or predominant antibodies, those with concurrent anti-AMPAR or antiNMDAR encephalitis were more likely to have active tumors (mainly thymoma), multiple autoantibodies, and the pattern of brain immunostaining was usually composed of the expected mix of immunoreactivities. Moreover, in this group of patients, the syndrome and outcome were consistent with those of the accompanying antibodies and tumors. ${ }^{7}$ These findings suggest that the GluK2

to those of cells treated for 30 minutes with 2 different patients' serum (patient $1=289.1 \pm 39.22 \mathrm{pA} / \mathrm{pF}$; and patient $2=324.9 \pm 64.1 \mathrm{pA} / \mathrm{pF}$ ); $p>0.99 ; n=15$ recordings for each group from 3 independent experiments, Kruskal-Wallis with Dunn's comparison test. However, cells treated for 5 hours with the same 2 patients' serum showed a significant reduction of GluK2-mediated currents compared with the control serum (patient $1=142.3 \pm 45.41 \mathrm{pA} / \mathrm{pF}$, and patient $5=145.8 \pm 23.64$ $\mathrm{pA} / \mathrm{pF}$ vs. control $=317 \pm 36.84 \mathrm{pA} / \mathrm{pF}) ; * \mathrm{p}=0.0019$ and $* * p=0.006$, respectively; 3 independent experiments and at least $\mathrm{n}=8$ recordings; Kruskal-Wallis with Dunn's comparison test. (C) Binding of patients' antibodies to HEK cells expressing GluK2 after incubations of $\mathbf{3 0}$ minutes and $\mathbf{5}$ hours. Internalization of receptors is only visible after $\mathbf{5}$ hours (red fluorescence). Even though there is intense antibody binding at 30 minutes, no electrophysiological effects were observed (A, B). These findings suggest that the reduction of GluK2-mediated currents is secondary to the antibody-mediated internalization of receptors rather than a direct antagonistic (or blocking) effect on receptor function, in which case electrophysiological changes would be visible at 30 minutes. Scale bar $=10 \mu \mathrm{m}$. 


\begin{tabular}{|c|c|c|c|c|c|c|}
\hline $\begin{array}{l}\text { Case \# } \\
\text { Sex/age }\end{array}$ & $\begin{array}{l}\text { Concurrent } \\
\text { antibodies }\end{array}$ & Main syndrome & Brain MRI & CSF & Tumor & Follow-up, outcome \\
\hline $\begin{array}{l}9 \\
M / 67\end{array}$ & $\begin{array}{l}\text { AMPAR, } \\
\text { GluK2, 1, } 3\end{array}$ & Limbic encephalitis $^{\mathrm{a}}$ & $\begin{array}{l}\text { FLAIR/T2 } \\
\text { increased signal in } \\
\text { medial temporal } \\
\text { lobes }\end{array}$ & $\begin{array}{l}\text { WBC N } \\
\text { Prot N }\end{array}$ & No & $\begin{array}{l}3 \text { months, died in the } \\
\text { acute phase of the } \\
\text { disease (sepsis) }\end{array}$ \\
\hline $\begin{array}{l}10 \\
F / 70\end{array}$ & $\begin{array}{l}\text { AMPAR, } \\
\text { GluK2 }\end{array}$ & $\begin{array}{l}\text { Acute presentation of } \\
\text { short-term memory } \\
\text { loss, confused, } \\
\text { disoriented }\end{array}$ & Normal & $\begin{array}{l}\text { WBC N } \\
\text { Prot } 64\end{array}$ & SCLC & $\begin{array}{l}\text { Partial improvement, } \\
\text { died of cancer } 39 \text { mo } \\
\text { after symptom onset }\end{array}$ \\
\hline $\begin{array}{l}11 \\
F / 44\end{array}$ & $\begin{array}{l}\text { AMPAR, } \\
\text { CRMP5, } \\
\text { GluK2, } 1\end{array}$ & Limbic encephalitis $^{a}$ & N/A & $\begin{array}{l}\text { WBC } 15 \\
\text { Prot, N }\end{array}$ & Thymoma & $\begin{array}{l}\text { No improvement. } \\
\text { Autopsy confirmed } \\
\text { inflammatory } \\
\text { infiltrates in both } \\
\text { temporal lobes. }\end{array}$ \\
\hline $\begin{array}{l}12 \\
F / 51\end{array}$ & $\begin{array}{l}\text { AMPAR, } \\
\text { CRMP5, } \\
\text { GluK2, } 1\end{array}$ & $\begin{array}{l}\text { Acute confusion, } \\
\text { memory loss, } \\
\text { asymmetric weakness } \\
\text { in arms and legs }\end{array}$ & N/A & $\begin{array}{l}\text { WBC N } \\
\text { Prot, N }\end{array}$ & Thymoma & N/A \\
\hline $\begin{array}{l}13 \\
F / 41\end{array}$ & $\begin{array}{l}\text { AMPAR, } \\
\text { GABAbR, } \\
\text { CASPR2, } \\
\text { GluK2, 1, } 3\end{array}$ & Limbic encephalitis $^{\mathrm{a}}$ & $\begin{array}{l}\text { FLAIR/T2 } \\
\text { increased signal in } \\
\text { medial temporal } \\
\text { lobes }\end{array}$ & $\begin{array}{l}\text { WBC } 10 \\
\text { Prot, N }\end{array}$ & $\begin{array}{l}\text { Metastatic } \\
\text { thymoma }\end{array}$ & N/A \\
\hline $\begin{array}{l}14 \\
F / 14\end{array}$ & $\begin{array}{l}\text { NMDAR, } \\
\text { GluK2 }\end{array}$ & $\begin{array}{l}\text { Anti-NMDAR } \\
\text { encephalitis }^{\mathrm{a}}\end{array}$ & Normal & $\begin{array}{l}\text { WBC } 63 \\
\text { Prot N }\end{array}$ & No & $\begin{array}{l}\text { Substantial recovery; } \\
\text { mild residual deficits } \\
\text { in processing speed }\end{array}$ \\
\hline \multicolumn{7}{|c|}{$\begin{array}{l}\text { aPatients with typical clinical manifestations of limbic or anti-NMDAR encephalitis. } \\
\text { AMPAR = alpha-amino-3-hydroxy-5-methyl-4-isoxazolepropionic acid receptor; } \mathrm{CSF}=\text { cerebrospinal fluid; } \mathrm{F}=\text { female; FLAIR }=\text { Fluid-attenuated } \\
\text { inversion recovery; } \mathrm{M}=\text { male; MRI = magnetic resonance imaging; } \mathrm{N}=\text { normal; } \mathrm{NMDAR}=\mathrm{N} \text {-methyl-D-aspartate receptor; Prot }=\text { protein concen- } \\
\text { tration }(\mathrm{mg} / \mathrm{dl}) ; \mathrm{SCLC}=\text { small-cell lung carcinoma; } \mathrm{WBC}=\text { white blood cell count }(\mathrm{cell} / \mathrm{s} / \mu \mathrm{l}) \text {. }\end{array}$} \\
\hline
\end{tabular}

epitopes in both groups of patients may differ and are probably less clinically relevant in the second group. Future studies with immunocompetition between samples representative of both groups of patients may clarify this hypothesis, but the currently available small amounts of serum/CSF prevented us to perform this experiment.

We found that a prolonged treatment ( $>5$ hours) of GluK2-expressing HEK293 cells with patients' samples induced a robust reduction of GluK2-mediated currents that was not observed after a short treatment ( $\sim 30$ minutes), suggesting that the impairment of GluK2-currents was secondary to the reduced cell-surface receptors (remaining fraction, not internalized) rather than an antagonistic effect of the antibody on receptor function. This paradigm is similar to the pathogenic mechanisms described in other anti-glutamate receptor encephalitis $\left(\mathrm{NMDAR}^{9,31}\right.$ or $\left.\mathrm{AMPAR}^{10,32}\right)$ that are largely mediated by internalization of receptors, whereas for GlyR antibodies a robust antagonistic effect (along with mild to moderate internalization), have been demonstrated. $^{21,33}$

Although several autoimmune encephalitis can manifest with cerebellar symptoms, they almost never present as acute cerebellitis. ${ }^{1}$ The fact that 4 of 8 patients with GluK2-only or predominant antibodies developed early and prominent clinical or MRI findings of cerebellarbrainstem dysfunction or cerebellitis (causing obstructive hydrocephalus in 2 patients) is notable and provide a clue to suspect this disorder. In general, most reported patients with acute cerebellitis are children or young adults and they usually respond to steroids. ${ }^{34,35}$ GluK2-abs represent the first relevant antibody found in patients with this syndrome. In 5 Japanese children with acute cerebellitis, IgM or IgG antibodies against the glutamate receptor delta 
2 were identified. ${ }^{36-38}$ Unlike the GluK2-abs reported here, the clinical or pathogenic significance of glutamate receptor delta 2 antibodies is unclear as they have also been described in multiple different disorders. ${ }^{39-41}$

In contrast to the group of patients with GluK2-only or predominant antibodies, none of the 6 patients with GluK2-abs concurrent with antiAMPAR encephalitis (with or without CRMP5 antibodies) or anti-NMDAR encephalitis, and none of the additional randomly selected 138 patients with antiNMDAR or AMPAR encephalitis, developed acute cerebellitis, obstructive hydrocephalus, or opsoclonusmyoclonus (data not shown). However, some of these features, such as cerebellar dysfunction with AMPAR antibodies, ${ }^{8}$ or opsoclonus with NMDAR antibodies, ${ }^{42,43}$ have been reported and it is unknown whether they had GluK2-abs.

Our study has limitations posed by the retrospective analysis and small number of cases that usually occurs in first descriptions of autoimmune encephalitis. ${ }^{5,15,44,45}$ The long-term outcome of patients with GluK-only antibodies is unclear because only 2 patients received immunomodulation (the rest of assessable cases only received steroids), 2 patients died in the acute phase of systemic complications, and 1 patient died 27 months after an episode of rapid progression of symptoms superimposed to slow progression of HIV-related deficits. However, 3 patients showed substantial improvement, one with full recovery, suggesting that prompt diagnosis and an immunotherapy approach similar to that used in other autoimmune encephalitis may be effective.

The current findings have important clinical implications. GluK2 antibody-associated encephalitis should be suspected in cases of rapid presentation of encephalitis of unknown cause with clinical-radiological cerebellar involvement, ranging from mild cerebellar symptoms to severe cerebellitis, which may be accompanied by extensive MRI T2-FLAIR abnormalities not restricted to the cerebellum. Accompanying findings may include encephalopathy (memory deficit, behavioral change, and seizures), signs of corticospinal tract involvement (hyperreflexia, upgoing toes, and ataxic-spastic gait), or opsoclonus-myoclonus. At symptom onset, patients should be monitored for potential life-threatening posterior fossa edema and obstructive hydrocephalus. If possible, antibodies should be examined in CSF and serum with CBA and brain immunostaining. The presence of concurrent AMPA or NMDAR antibodies associates with syndromes and comorbidities usually related to these antibodies. Future studies should focus on refining epitope-syndrome associations, assess the efficacy of immunotherapy, and develop animal models of the disease.

\section{Acknowledgments}

The authors thank Esther Aguilar and Mercedes Alba for their excellent technical support, and Ana Valero Paternain and Juan Lerma (Instituto de Neurociencias de Alicante) for providing the GluK2(Q) DNA construct and the GluK2 knockout mouse brain tissue.

The proteomics analyses were performed in the CRG/UPF Proteomics Unit, which is part of the Spanish Infrastructure for Omics Technologies (ICTS OmicsTech) and member of the ProteoRed, PRB3, supported by grant PT17/0019 of the PE I + D + i 2013-2016 funded by ISCIII and ERDF. Fondo Europeo de Desarrollo Regional (FEDER) - Ministerio de Ciencia e Innovación (BFU2017-83317-P) to D.S. Fondo Europeo de Desarrollo Regional (FEDER) - Instituto de Salud Carlos III (FIS PI17/00296 and RD16/0008/0014 to X.G.; FIS PI018/00067 to LS; FIS PI18/00486 to T.A.; JR17/00012 to E.M.H.; FIS 20/00197 to J.D., and Proyecto Integrado de Excelencia 16/00014 to J.D.); Pla estratègic de recerca i innovació en salut (PERIS), Departament de Salut, Generalitat de Catalunya (SLT006/17/00362 to T.A.); Generalitat de Catalunya 2017SGR737 to X.G.. Ministerio de Ciencia e Innovación, Maria de Maeztu MDM-2017-0729 to D.S. and X.G.; ERA-NET NEURON (to J.D.); Generalitat de Catalunya (FI-AGAUR grant program; 2019FI_B1 00212, to A.G.S.); Resident Award "Josep Font," Hospital Clínic to M.G.; Basque Government Doctoral Fellowship Programme, (PRE_2019_1_0255) to E.M. Grants from Torrons Vicenç foundation (PFNR0144 to T.A.), Pablove Foundation (689368 to T.A.), "La Caixa" Foundation (to J.D.); Edmond J Safra Foundation (to J.D.); Fundació Cellex (to J.D.).

\section{Author Contributions}

J.D., L.S., F.G., and X.G. contributed to the conception and design of the study. J.L., M.G., L.S., J.D., F.G., A.S., D.S., F.M.-C., J.G., T.M., F.O., F.Z., V.K., P.F., J.H., M.T., M.S., E.M.-H., T.A., and J.P. contributed to the acquisition and analysis of data. J.D., M.G., L.S., F.G., J.P., and D.S. contributed to drafting the text or preparing the figures. Members of the GluK2 Encephalitis Study Group contributed to the acquisition of data and can be found in Supplementary Table S1.

\section{Potential Conflicts of Interest}

The authors have no conflicts of interest related to this study. 


\section{References}

1. Dalmau J, Graus F. Antibody-mediated encephalitis. N Engl J Med 2018;378:840-851.

2. Traynelis SF, Wollmuth LP, McBain CJ, et al. Glutamate receptor ion channels: structure, regulation, and function. Pharmacol Rev 2010; 62:405-496.

3. Contractor A, Mulle C, Swanson GT. Kainate receptors coming of age: milestones of two decades of research. Trends Neurosci 2011; 34:154-163.

4. Dalmau J, Gleichman AJ, Hughes EG, et al. Anti-NMDA-receptor encephalitis: case series and analysis of the effects of antibodies. Lancet Neurol 2008;7:1091-1098.

5. Lai M, Hughes EG, Peng $X$, et al. AMPA receptor antibodies in limbic encephalitis alter synaptic receptor location. Ann Neurol 2009;65: 424-434

6. Titulaer MJ, McCracken L, Gabilondo I, et al. Treatment and prognostic factors for long-term outcome in patients with anti-NMDA receptor encephalitis: an observational cohort study. Lancet Neurol 2013;12:157-165.

7. Hoftberger R, van Sonderen A, Leypoldt F, et al. Encephalitis and AMPA receptor antibodies: novel findings in a case series of 22 patients. Neurology 2015;84:2403-2412.

8. Joubert B, Kerschen P, Zekeridou A, et al. Clinical spectrum of encephalitis associated with antibodies against the alpha-amino3-hydroxy-5-methyl-4-isoxazolepropionic acid receptor: case series and review of the literature. JAMA Neurol 2015;72:1163-1169.

9. Hughes EG, Peng X, Gleichman AJ, et al. Cellular and synaptic mechanisms of anti-NMDA receptor encephalitis. J Neurosci 2010; 30:5866-5875

10. Haselmann $H$, Mannara F, Werner $C$, et al. Human autoantibodies against the AMPA receptor subunit GluA2 induce receptor reorganization and memory dysfunction. Neuron 2018;100:91-105.e109.

11. Christensen JK, Paternain AV, Selak S, et al. A mosaic of functional kainate receptors in hippocampal interneurons. J Neurosci 2004;24: 8986-8993.

12. Ances BM, Vitaliani R, Taylor RA, et al. Treatment-responsive limbic encephalitis identified by neuropil antibodies: MRI and PET correlates. Brain 2005;128:1764-1777.

13. Landa J, Guasp M, Petit-Pedrol M, et al. Seizure-related 6 homolog like 2 autoimmunity: neurologic syndrome and antibody effects. Neurol Neuroimmunol Neuroinflamm 2021;8:e916.

14. Lynch DR, Lawrence JJ, Lenz S, et al. Pharmacological characterization of heterodimeric NMDA receptors composed of NR 1a and 2B subunits: differences with receptors formed from NR $1 a$ and $2 A$. J Neurochem 1995;64:1462-1468.

15. Dalmau J, Tuzun E, Wu HY, et al. Paraneoplastic anti-N-methyl-Daspartate receptor encephalitis associated with ovarian teratoma. Ann Neurol 2007;61:25-36.

16. Arino $H$, Armangue $T$, Petit-Pedrol M, et al. Anti-LGl1-associated cognitive impairment: presentation and long-term outcome. Neurology 2016;87:759-765.

17. Sabater L, Gaig C, Gelpi E, et al. A novel non-rapid-eye movement and rapid-eye-movement parasomnia with sleep breathing disorder associated with antibodies to IgLON5: a case series, characterisation of the antigen, and post-mortem study. Lancet Neurol 2014;13: 575-586.

18. Planaguma J, Leypoldt F, Mannara F, et al. Human N-methyl Daspartate receptor antibodies alter memory and behaviour in mice. Brain 2015;138:94-109.

19. Planaguma J, Haselmann $H$, Mannara $F$, et al. Ephrin-B2 prevents Nmethyl-D-aspartate receptor antibody effects on memory and neuroplasticity. Ann Neurol 2016;80:388-400.
20. Bettler B, Egebjerg J, Sharma G, et al. Cloning of a putative glutamate receptor: a low affinity kainate-binding subunit. Neuron 1992; 8:257-265.

21. Crisp SJ, Dixon CL, Jacobson L, et al. Glycine receptor autoantibodies disrupt inhibitory neurotransmission. Brain 2019;142: 3398-3410

22. Moscato EH, Peng $X$, Jain A, et al. Acute mechanisms underlying antibody effects in anti-N-methyl-D-aspartate receptor encephalitis. Ann Neurol 2014;76:108-119.

23. Egebjerg J, Heinemann SF. Ca2+ permeability of unedited and edited versions of the kainate selective glutamate receptor GluR6. Proc Natl Acad Sci U S A 1993;90:755-759.

24. Burnashev N, Villarroel A, Sakmann B. Dimensions and ion selectivity of recombinant AMPA and kainate receptor channels and their dependence on Q/R site residues. J Physiol 1996;496:165-173.

25. Sommer B, Kohler M, Sprengel R, Seeburg PH. RNA editing in brain controls a determinant of ion flow in glutamate-gated channels. Cell 1991;67:11-19.

26. Pinheiro PS, Mulle C. Presynaptic glutamate receptors: physiological functions and mechanisms of action. Nat Rev Neurosci 2008;9: 423-436.

27. Lerma J. Kainate receptor physiology. Curr Opin Pharmacol 2006;6: 89-97

28. Contractor A, Swanson G, Heinemann SF. Kainate receptors are involved in short- and long-term plasticity at mossy fiber synapses in the hippocampus. Neuron 2001;29:209-216.

29. Schmitz D, Mellor J, Breustedt J, Nicoll RA. Presynaptic kainate receptors impart an associative property to hippocampal mossy fiber long-term potentiation. Nat Neurosci 2003;6:1058-1063.

30. Lourenco J, Cannich A, Carta M, et al. Synaptic activation of kainate receptors gates presynaptic $\mathrm{CB}(1)$ signaling at GABAergic synapses. Nat Neurosci 2010;13:197-204.

31. Mikasova L, De Rossi $P$, Bouchet D, et al. Disrupted surface cross-talk between NMDA and Ephrin-B2 receptors in anti-NMDA encephalitis. Brain 2012;135:1606-1621.

32. Peng $X$, Hughes EG, Moscato $E H$, et al. Cellular plasticity induced by anti-alpha-amino-3-hydroxy-5-methyl-4-isoxazolepropionic acid (AMPA) receptor encephalitis antibodies. Ann Neurol 2015;77: 381-398.

33. Rauschenberger V, von Wardenburg N, Schaefer N, et al. Glycine receptor autoantibodies impair receptor function and induce motor dysfunction. Ann Neurol 2020;88:544-561.

34. Van Samkar A, Poulsen MNF, Bienfait HP, Van Leeuwen RB. Acute cerebellitis in adults: a case report and review of the literature. BMC Res Notes 2017;10:610.

35. Emelifeonwu JA, Shetty J, Kaliaperumal C, et al. Acute Cerebellitis in children: a variable clinical entity. J Child Neurol 2018;33: 675-684.

36. Shimokaze $T$, Kato $M$, Yoshimura $Y$, et al. A case of acute cerebellitis accompanied by autoantibodies against glutamate receptor delta2. Brain Dev 2007;29:224-226.

37. Shiihara T, Kato M, Konno A, et al. Acute cerebellar ataxia and consecutive cerebellitis produced by glutamate receptor delta2 autoantibody. Brain Dev 2007;29:254-256.

38. Kubota M, Takahashi Y. Steroid-responsive chronic cerebellitis with positive glutamate receptor delta 2 antibody. J Child Neurol 2008; 23:228-230.

39. Berridge G, Menassa DA, Moloney $T$, et al. Glutamate receptor delta2 serum antibodies in pediatric opsoclonus myoclonus ataxia syndrome. Neurology 2018;91:e714-e723.

40. Matsumoto $H$, Okabe S, Hirakawa-Yamada $M$, et al. Steroidresponsive focal epilepsy with focal dystonia accompanied by glutamate receptor delta2 antibody. J Neuroimmunol 2012;249:101-104. 
41. Fukuoka $T$, Takeda $H$, Ohe $Y$, et al. Anti-glutamate receptor delta2 antibody-positive migrating focal encephalitis. Clin Neurol Neurosurg 2012;114:1351-1354.

42. Kurian M, Lalive PH, Dalmau JO, Horvath J. Opsoclonus-myoclonus syndrome in anti-N-methyl-D-aspartate receptor encephalitis. Arch Neurol 2010;67:118-121.

43. Armangue T, Sabater L, Torres-Vega E, et al. Clinical and immunological features of Opsoclonus-myoclonus syndrome in the era of neuronal cell surface antibodies. JAMA Neurol 2016;73:417-424.
44. Lancaster E, Lai M, Peng X, et al. Antibodies to the GABA(B) receptor in limbic encephalitis with seizures: case series and characterisation of the antigen. Lancet Neurol 2010;9:67-76.

45. Petit-Pedrol M, Armangue T, Peng $X$, et al. Encephalitis with refractory seizures, status epilepticus, and antibodies to the GABAA receptor: a case series, characterisation of the antigen, and analysis of the effects of antibodies. Lancet Neurol 2014;13:276-286. 